\title{
Sand sheets interaction with aeolian dune, alluvial and marginal playa beds in Late Permian Upper Rotliegend setting (western part of the Poznań Basin, Poland)
}

\author{
Hubert KIERSNOWSKI ${ }^{1, *}$ and Arkadiusz BUNIAK ${ }^{2}$ \\ 1 Polish Geological Institute - National Research Institute, Rakowiecka 4, 00-975 Warszawa, Poland \\ 2 Orlen Upstream, Prosta 70, 00-838 Warszawa, Poland
}

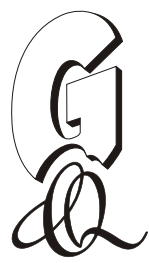

\begin{abstract}
Kiersnowski, H., Buniak, A., 2016. Sand sheets interaction with aeolian dune, alluvial and marginal playa beds in Late Permian Upper Rotliegend setting (western part of the Poznań Basin, Poland). Geological Quarterly, 60 (4): 771-800, doi: 10.7306/gq.1336

The Upper Rotliegend deposits of the western part of the Poznań Basin, Poland, represent three main sedimentary environments: aeolian desert (dunes and sand sheets), alluvial plain (alluvial covers with wadi deposits) and marginal playa. In arid periods, dunes prograded into areas dominated by alluvial sedimentation. During wet periods, alluvial deposits eroded the aeolian deposits and prograded onto dune fields. Playa sediments were deposited among aeolian or alluvial sediments during periodic expansions of the playa. These aeolian, alluvial and playa deposits are arranged in depositional sequences. Boundaries between sequences are marked by rapid changes in depositional facies; and by erosional bounding surfaces. Maximum Wetting Surfaces have been distinguished within some parts of the depositional sequences, which enable regional correlations. The sections studied are composed of thick sequences of sand and sand-gravel sheets. The sand sheets represent periods of stratigraphic condensation. Systems of sand sheets are typical of marginal areas of ergs. We distinguish nine depositional complexes (units) numbered 1-9 from base to top, respectively. These subdivisions are based on the interpretation of the sedimentological record in palaeoclimatic terms, and in terms of major erosional boundaries, which are probably of regional extent. In the aeolian deposits, major boundaries are associated with deflation surfaces related to the stabilization of groundwater levels. In the marginal playa deposits, the most important boundaries are correlated to transgressive surfaces that developed during playa expansion. Time gaps represented by the boundaries and the scale of erosion below them, are difficult to estimate. The depositional system of the Upper Rotliegend was dominated by sand and sand-gravel sheets, and is either a unique feature in the entire Southern Permian Basin or, as we assume, sand sheets occur more commonly in the Rotliegend than has been previously thought.
\end{abstract}

Key words: Upper Rotliegend, sand sheet, marginal playa, Poznań Basin, Poland, Late Permian climate.

\section{INTRODUCTION}

The Polish Rotliegend Basin is an eastern element of the Southern Permian Basin. It has a complex tectonic framework. In the north-east, the basement of the Permian Basin consists of Carboniferous and Devonian rocks of the Variscan Foredeep. In the south-west, the basement consists of Carboniferous rocks of the outer Variscides and Permo-Carboniferous volcanic rocks. Tectonic and geomorphic diversity of the sub-Permian basement resulted in a variable development of the Permian sedimentary cover, in terms of both lithofacies and thickness. The sedimentary Rotliegend is represented by deposits of aeolian, playa and alluvial environments (Kiersnowski et al., 1995; Kiersnowski, 1997; McCann et al., 2008).

This paper discusses the controls of the Rotliegend deposition in the western part of the Poznań Basin (the Pniewy and

\footnotetext{
* Corresponding author, e-mail: hubert.kiersnowski@pgi.gov.pl
}

Received: October 26, 2016; accepted: December 17, 2016; first published online: December 23, 2016
Obrzycko region) in western Poland; located at the boundary of the Variscan externides and their foredeep (Fig. 1). Here, all of the above-mentioned types of sedimentary environments occur. The development and extent of the individual depositional systems were controlled by palaeoclimatic conditions and palaeogeomorphological controls within the basin. In part, these systems were due to the effect of syndepositional tectonic movements.

\section{GEOLOGICAL SETTING}

The Rotliegend deposits in western Poland overlie the older basement, which consists of: Lower Carboniferous rocks (Wierzchowska-Kicułowa, 1984), Lower Permian volcanic rocks (Ryka, 1989; Jackowicz, 1994) and Lower Rotliegend sedimentary and pyroclastic rocks (Maliszewska et al., 2003).

The geological structure of the basement of the Upper Rotliegend sedimentary rocks is the result of multi-phase tectonic activity, accompanied by volcanism. This was followed by multi-stage erosional processes. The key element, in shaping the present-day structural framework of the area, was the Variscan structural pattern of the Late Carboniferous, in the 


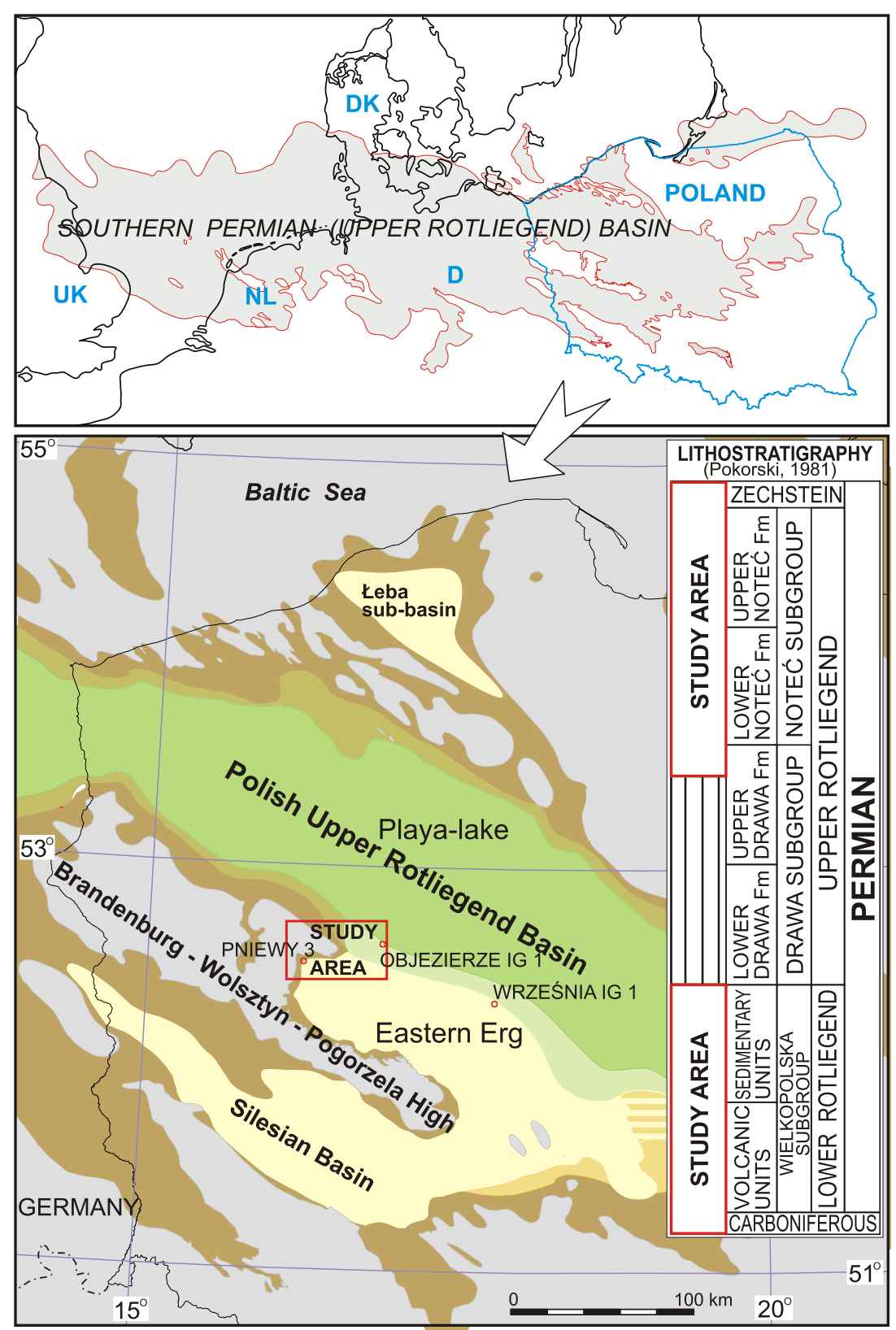

playa-lake mudstones, claystones and fine sandstones marginal playa sandstones and mudstones

marginal playa sandstones and mudstones interbedding with aeolian sands or capped by aeolian dunes

aeolian dunes and interdunes sandstones

alluvial/fluvial plain sandstones and mudstones interbedding with aeolian sands or capped by aeolian dunes

alluvial fan sandstones and conglomerates with rare aeolian dunes

source area without Rotliegend deposits

Fig. 1. Study area: lithostratigraphy and topmost Upper Rotliegend sedimentary environments and main lithofacies

Quadrangle indicates the area shown in Figure 2

zone of the northern Variscan externides (Maliszewska et al., 2003; Kiersnowski, 2014).

The next important structural-geomorphic element was a massive, several-hundred metres thick, lava and tuff cover that developed during the Late Carboniferous-Early Permian volcanic activity. This was accompanied by the deposition of Early Permian clastic sediments (Geißler et al., 2008) that, in the study area, have been distinguished as an informal lithostratigraphic unit (Pniewy Formation - Maliszewska et al., 2003; Kiersnowski, 2014).

The next stage, in the development of the relief of the sub-Upper Permian basement, occurred during a significant and long-lasting erosion process that was accompanied by partial tectonic restructuring. The formation of the Late Permian sedimentary cover, composed of the Upper Rotliegend deposits, was a result of the development of a long-term accommodation space in the western part of the Poznań Basin. This space was successively filled with the Rotliegend deposits that gradually masked the relief variations of the older basement, including those of tectonic origin.

Ultimately, this lead to significant levelling of the palaeorelief (Głowacki et al., 1993; Weihe, 1997; Buniak, 1999). Inundation of the Zechstein Sea terminated the Upper Rotliegend sedimentation in this region (Wagner, 1994).

The Upper Rotliegend deposits of the western Poznań Graben consist of aeolian sandstone lithofacies found in the western part of the Eastern Erg (Kiersnowski, 1997, 2013; Buniak and Kiersnowski, 2010). These deposits also consist of mudstone-sandstone lithofacies of the marginal playa, which constitutes the southwestern part of a vast playa-lake. This lake occupied the central area of the Polish Rotliegend Basin (Gast et al., 2010; Kiersnowski, 2013). Additionally, sandstone-conglomerate lithofacies, representing an alluvial system, developed along palaeogeomorphic edges in the eastern part of the Poznan Basin (Fig. 1).

The Upper Rotliegend deposits in the western part of the Poznań Basin are stratigraphically condensed and feature a lower thickness, as compared to their lithostratigraphic equivalents from the central and eastern parts of the basin.

The Upper Rotliegend, from the western part of the Poznan Graben, analysed for the present study, represents the Noteć Formation (Pokorski, 1988b; cf. Karnkowski, 1994; Fig. 1). In the central, eastern and southeastern parts of the Poznan Graben, there are also deposits representing the lower part of the Upper Rotliegend - the Drawa Formation (Fig. 1)

The southwestern part of the Poznań Basin is bound, in the south, by a tectonic element called the Wolsztyn Ridge. This depositional system, described by Kiersnowski et al. (2010), consists of alluvial and aeolian sediments, similar to that of the Pniewy region. The Wolsztyn Ridge, like the Gnuszyn-Nowy Tomyśl Ridge located to the west, is composed of Lower Carboniferous and volcanic rocks. These rocks are the major component of conglomerates deposited in the alluvial fan system developed along the northern slope of the Wolsztyn Ridge. The alluvial fan deposits are interbedded with thick complexes of aeolian sandstones and fluvial channel sandstones (Kiersnowski et al., 2010). 
Aeolian sandstones are the reservoir rocks for hydrocarbon accumulations, and the study area hosts a number of gas fields, including Pniewy, Podrzewie, Duszniki, Młodasko and Rokietnica (P. Karnkowski, 1999) managed by the Polish Oil and Gas Company (POGC).

\section{MATERIAL AND METHODS}

Sedimentological analysis of drill cores and on-well logs from 29 boreholes drilled in the area included: Brody 1; Duszniki 1, 2 and 3; Gaj 2; Golęczewo 1; Kaźmierz 1; Młodasko 1, 2, 3, 5 and 6; Objezierze IG 1; Obrzycko 1 and 3; Piersko 1; Pniewy 1, 2, 3 and 4; Podrzewie 1,2 and 3; Rokietnica 1,2 and 3; Sokolniki 1; Stramnica 1; and Wilczyna 1a (Fig. 2). Lithological-sedimentological logs and photos of sedimentary structures are shown in Figures 3-17.

Our sedimentological study of the core was compared with well logs interpretation, as well as our knowledge of older basement geology and tectonic structures. Additionally, data from a number of nearby boreholes (located outside the area shown in Figure 2) have been used. This allowed us to construct palaeogeographic-lithofacies maps, shown in Figures 18-24. This interpretation depicts the view of the authors and is not necessarily compatible with existing ideas about the geological structure and geological evolution of the region during the Late Rotliegend time.

Tectonic analysis was performed using structural maps of the Zechstein base. A depth-converted map of reflection boundary PZ1' is included in the 3D seismic survey reports (POGC) of: Sieraków-Pniewy, Pniewy-Stęszew and Rokietnica-Młodasko, Brody I and II and 2D (Obrzycko-Szamotuły).

\section{RESULTS AND INTERPRETATION}

The study of drill cores made it possible to distinguish three major depositional systems: (1) alluvial fans and plains; (2) ae- olian - dunes and interdune areas, and sand and sand-gravel sheets; (3) marginal playa (Figs. 3-17).

The Rotliegend sections, in the closely located boreholes of Rokietnica 3, Rokietnica 1 and Rokietnica 2, consist of aeolian deposits up to the top (Fig. 4). This aeolian complex consists of dune and sand sheet deposits.

In the Rokietnica 1 borehole, dune deposits are dominant, while sand sheet deposits are of small thicknesses and concentrate in the upper portion of the section. The Rokietnica 2 section is similar, but incomplete coring makes it impossible to determine the proportion of sand sheet deposits in the lower part of the section. The upper part of the section contains thick sand sheets laminated by coarse sandstone. In contrast, the Rokietnica 3 section is dominated by deposits of well-developed dunes with rare and thin interbeds of sand sheet deposits. However, despite differences in sedimentation types, all three sections show a coarsening-upward succession (Fig. 4).

The depositional sequence shown in Figure 5 is the Rotliegend section from the Pniewy 3 borehole, see section location on Figure 16. It consists mainly of sand sheet and sand-gravel deposits, with interbeds of aeolian deposits. It is characterized by long-term accumulation, with subordinate alluvial deposits.

Sand sheets are represented by both finely laminated, fine and medium-grained sandstones. The lower part of the interval contains laminae of coarse-grained sandstone and scattered granule-size grains. In its upper part, coarse-grained sandstone lamination is more abundant and the proportion of granule-size grains is greater. The sand sheets are interbedded with aeolian deposits. These have been preserved within an erosionally truncated lower unit of the dunes.

Parts of initial dune base sedimentary units, with an initial low-angle lamination that increases toward the top, have been distinguished. Also distinguished are parts of progressive dune elements, with high-angle lamination, in the form of lamina sets of lee slope. They reflect dune migration on the surface of sand sheets. In some cases, ripple lamination is preserved in the sand sheet deposits.

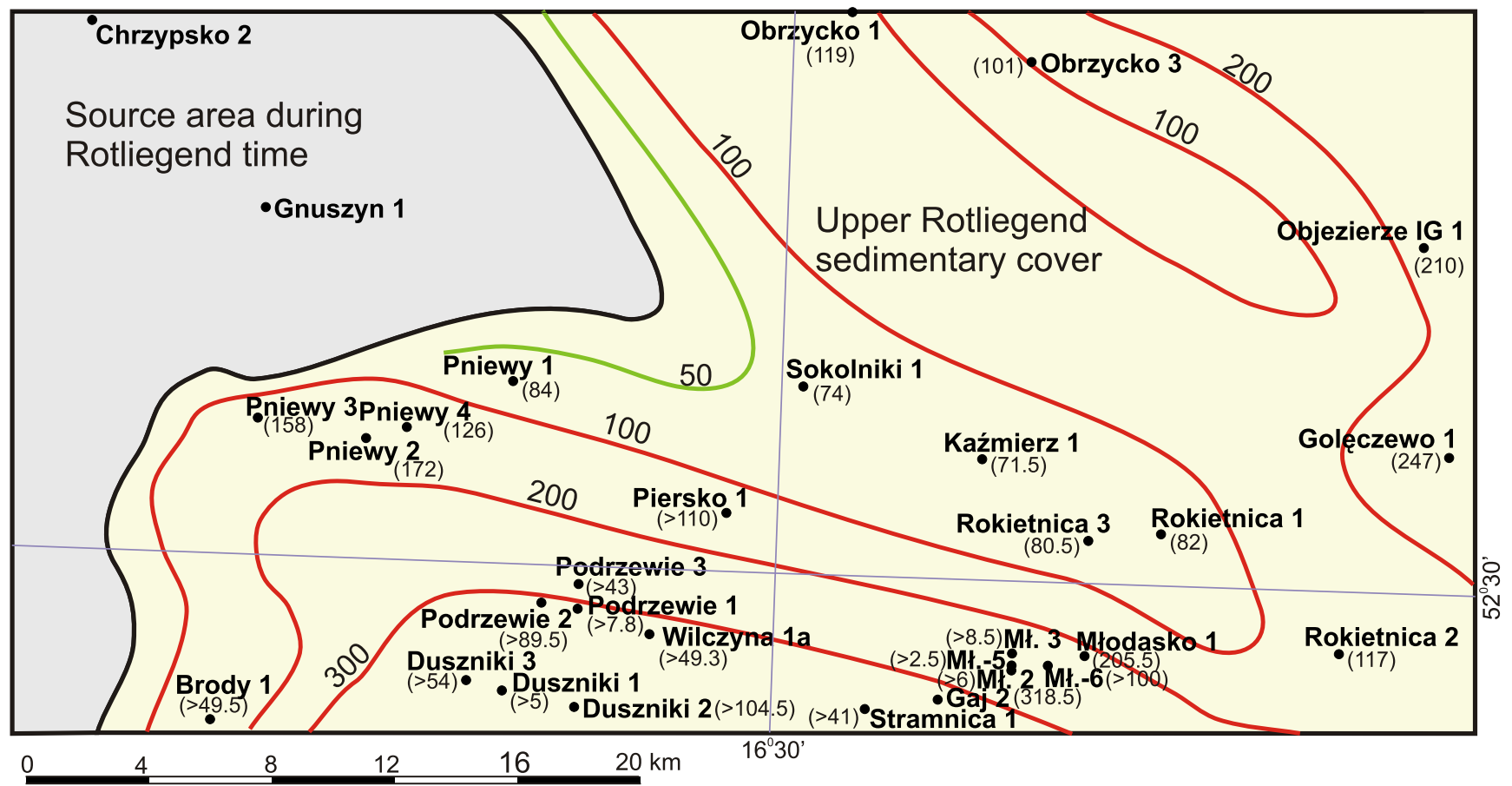

Fig. 2. Study area: location of boreholes studied and the thickness of Upper Rotliegend deposits 


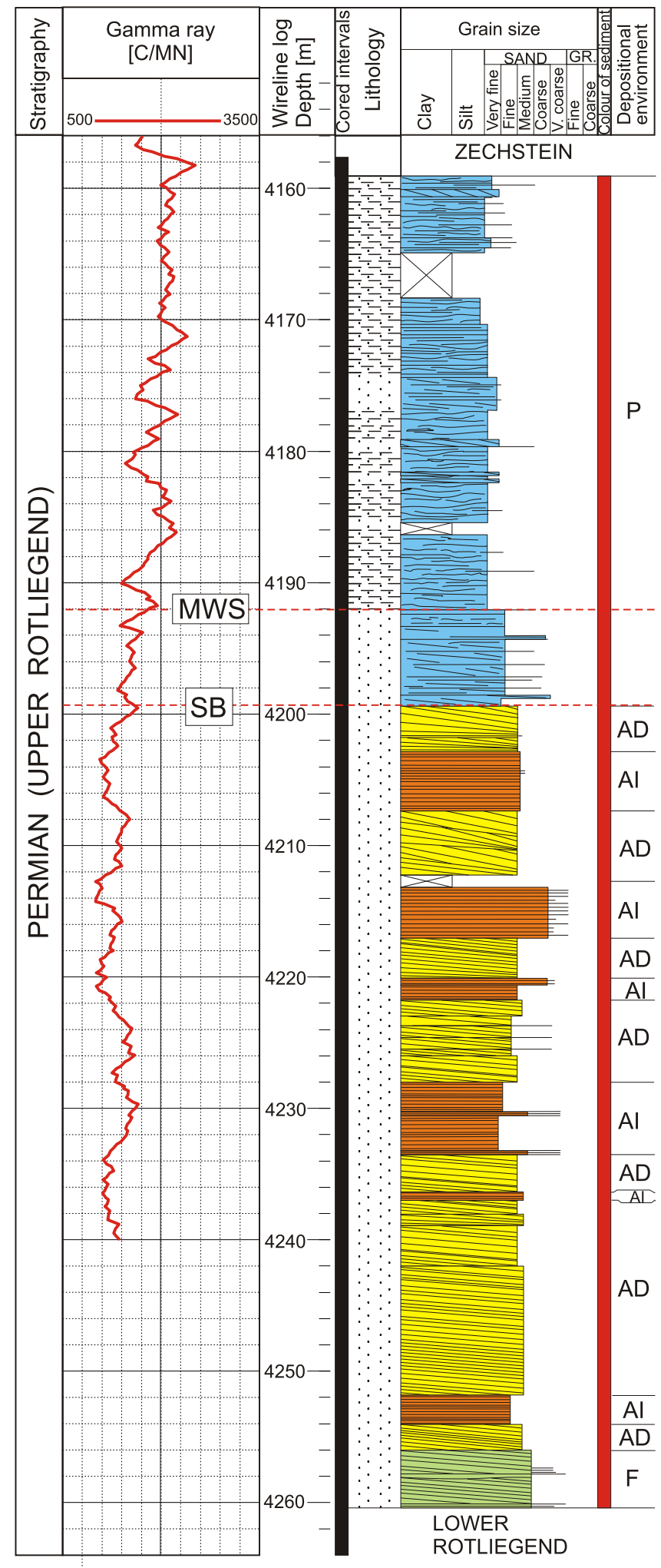

Fig. 3. Upper Rotliegend section from the Obrzycko 3 borehole

$\mathrm{AD}$ (yellow) - aeolian dune facies, $\mathrm{Al}$ (red-brown) - aeolian interdune facies (mostly sand sheet), F (green) - fluvial facies, P (blue) - playa facies; MWS - maximum wetting surface, SB - sequence boundary
Within the sand sheet deposits, shallow scour structures, wind-blown in nature, have been identified. In the core cross-section, larger deflation structures or erosional surfaces are visible as low-angle inclined lamina sets.

There are also erosional structures caused by periodic washouts of sand sheets. In some cases, very fine mud intraclasts are visible. They are indicative of periodic, short-term standing water on the surface of sand sheets (e.g., small pools after rainfall or remnants of interdune fine grained sediments).

The alluvial deposits, of greater thicknesses, which separate the sand sheets, represent sedimentary events such as floods which inundated the area dominated by the sand sheets. These flood deposits present as three types of depositional sequences which are massive and visually structureless; channelized with large-scale current structures (trough cross bedding), or small-scale current structures, or non-channelized sheet floods.

In the analysed interval, the alluvial deposits represent local clastic material (in terms of grain size). No coarser grains are observed. This might be evidence for a relatively nearby area dominated by sedimentation within alluvial fans.

The depositional sequence of the Pniewy 3 borehole shown in Figure 6 (see section location in Fig. 16) consists mainly of alluvial deposits with minor sand sheet and sand-gravel deposits. The sand sheets are represented by finely laminated, fine- and medium-grained sandstones. The lower intervals contain coarse-grained sandstone laminae and scattered granule-size grains. Greater proportions of granules are observed in the upper intervals. In some cases, aeolian ripple-mark lamination is preserved within the sand sheets. Within the sand sheet deposits, shallow scour structures, wind-blown in nature, were identified. There are also erosional structures caused by periodic washouts of sand sheets.

Alluvial deposits occur as sets of cyclic depositional sequences (fining-upward cycles), and as individual sequences separating sand sheets. These sequences represent a system of structureless floods and sheet floods, connected with distal alluvial fans. It is evidenced by the occurrence of coarser clastic material, represented by pebbles of volcanic rocks (up to $5 \mathrm{~cm}$ ). Small and larger mud and clay intraclasts ( $>6 \mathrm{~cm}$ across) are common. This proves the presence of periodic, short-term standing water on the surface of sheet flood deposits and within local distributary channels.

In this sedimentological section (Fig. 6), fining-upward cycles of stair type are observed, whose origin is discussed in the section on alluvial deposits.

As in the previously discussed interval, flood deposits are represented by three types of depositional sequences which are massive and visually structureless; channelized deposits with large-scale current structures, small-scale current structures, and non-channelized sheet floods. Large-scale current structures (trough and tabular cross bedding) are rare. Structureless flood deposits and non-channelized sheet flood deposits are dominant.

The depositional sequence shown in Figure 7 (see section location in Fig. 16) consists of alternating alluvial and dune deposits. The dunes are erosionally truncated by alluvial deposits. Their original thickness, from the period preceding each succeeding erosional event, is not known. Undoubtedly, erosional potential of alluvial deposits is much greater as compared to, e.g., the deflation process of alluvial sheets. Alluvial deposits occur as a series of cyclic depositional sequences (fining-upward cycles), and as individual sequences separating dune deposits.

The above described depositional sequences represent a system of massive, structureless floods and sheet floods asso- 
Rokietnica 3

Rokietnica 1

Rokietnica 2

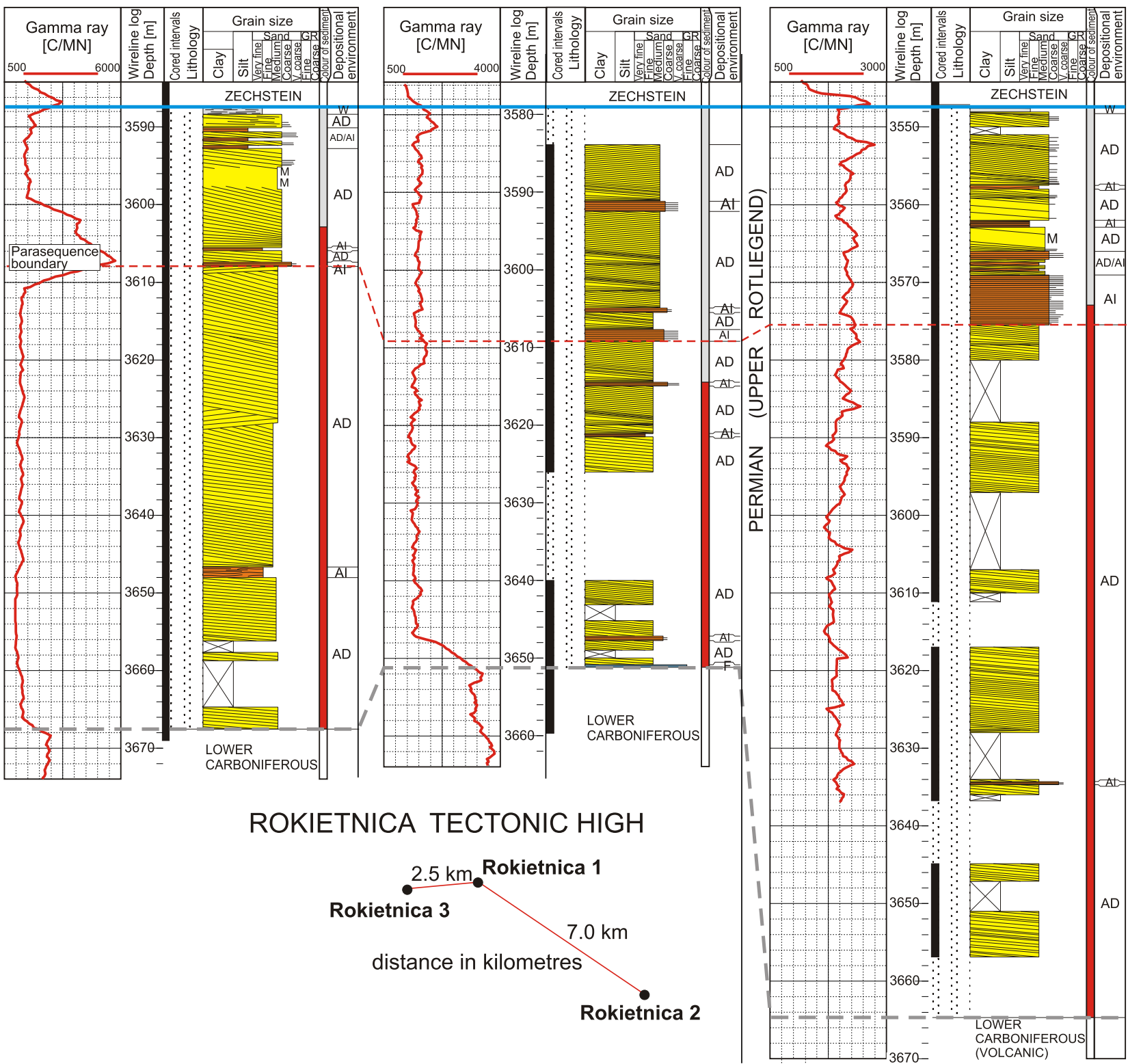

Fig. 4. Rotliegend sections of the boreholes: Rokietnica 3, Rokietnica 1 and Rokietnica 2, and their correlation

$$
\text { M - massive, W - Weissliegend; for other explanations see Figure } 3
$$

ciated with the distal alluvial fan (Fig. 8). This is evidenced by the presence of coarser clastic material represented by pebbles of volcanic rocks.

Smaller and greater mud and clay intraclasts (mostly angular clasts) are common. Their occurrence suggests periodic, short-term standing water on the surface of sheet floods and within local distributary channels. Large-scale current structures do not occur in this interval. Structureless flood and non-channelized sheet flood deposits are dominant (Fig. 8).

Aeolian deposits occur as preserved parts of lower dune elements. Parts of the initial dune base sedimentary units, which begin with low-angle lamination and show a gradual upward-increase in dip angle, have been distinguished. Also distinguished are parts of progressive dune elements, with high-angle lamination in the form of lamina sets of lee slope. These reflect dune migration on the surface of sand sheets. Part of a larger complex dune, consisting of sets of high-angle laminae, is described from the lower portion of the interval.

The depositional sequence shown in Figure 9 (cf. Fig. 16) is composed mainly of sand sheet and sand-gravel deposits with long-term sediment aggradation, as well as minor alluvial deposits. The sand sheets are represented by finely laminated, fine- and medium-grained sandstones. The lower intervals contain flat laminae of fine- and medium-grained sandstone, gradually passing upward into sand sheets with an admixture of coarse sandstone and scattered granule-size grains. The admixture of granule-size grains is interpreted as a sign of strong winds in aeolian depositional environment.

In the upper part of the interval, laminae of coarse sandstone are more numerous. Also, there is a greater admixture of granule-size grains, both scattered and in arranged laminae. The sand and sand-gravel sheets represent two coarsen- 
ing-upward cycles, separated by an aggradational sequence. The whole sand sheet and with grain coarsening upward sand-gravel sheet can be considered as single super-cycle. In the upper part of the interval, thin layers with wind-ripple structures are observed (Fig. 10).

The sand sheets are interbedded with aeolian deposits which are represented by preserved erosionally truncated parts

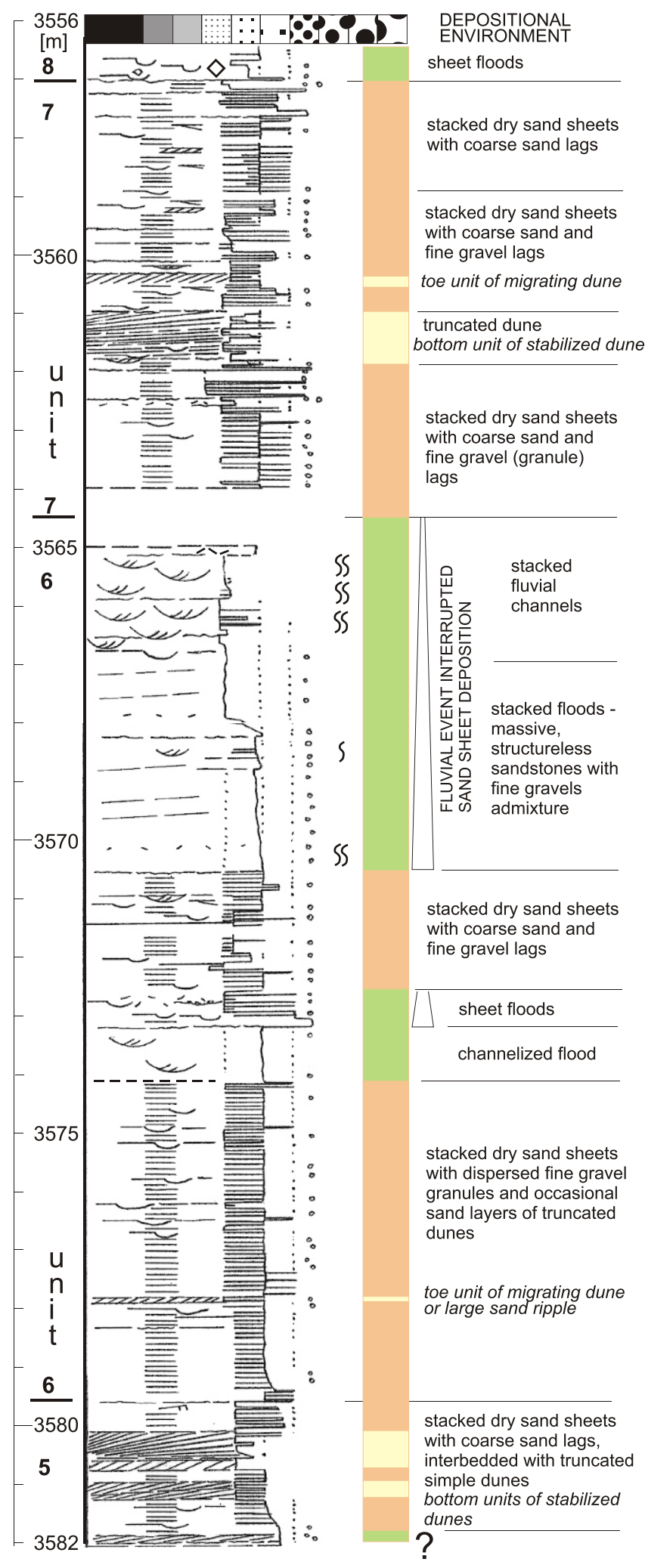

of lower dune elements. In the whole interval, the sand sheet deposits show wind-induced shallow scour structures. In the core cross-section, larger wind-induced deflation structures or erosional surfaces are visible as low-angle inclined lamina sets.

The lower part of the sand sheet interval contains shallow and deep erosional scours caused by periodic scouring of sand sheets. The fills of some erosional scours show current structures indicating a rapid water flow scouring of the sand sheet surfaces. The appearance of water, under circumstances of sand sheet accumulation, was probably related to torrential rains.

Alluvial deposits occur at the base and top of this specific sequence of sand sheets. These are flood deposits represented by channelized sediments with large current structures (trough cross bedding), and minor, non-channelized sheet floods. These alluvial deposits represent mostly local sedimentary material. Apart from the one exception, there are no coarser-grained sediments which could indicate a relatively nearby area dominated by sedimentation within alluvial fans.

The millimetre-scale, finely laminated sand sheet (Fig. 10) is composed of fine- and medium-grained sandstone with admixture of silt-sized grains. Well-sorted medium sand grains are visible as laminae. Coarse sand grains are irregularly scattered in the sediment. There are also single coarse grains attaining $3 \mathrm{~mm}$ across, close to the granule size. Small, low-angle inclined lamina sets are observed.

The sedimentological section shown in Figure 11 (cf. Fig. 16) is composed of aeolian deposits separated by fluvial deposits.

The lower part consists of sandstones representing compound dunes with variable dips and azimuths of lamina sets. The upper part is made up of lower elements of erosionally truncated single dunes, also with variable azimuths of lamina sets.

The middle part includes metre-scale thick fluvial deposits with current structures. There are also small convolute structures and single desiccation cracks.

The characteristic features of this complex are single bioturbation structures, root traces, and numerous large animal burrows exceeding $5 \mathrm{~cm}$ across. The burrows occur in both fluvial sediments and in the underlying aeolian dune deposits. Large animal burrows were observed along $>2 \mathrm{~m}$ vertical section. This significant occurrence of traces of organic activity is an extremely rare observation within the analysed Rotliegend deposits. An example of large burrows is shown in Figure 12. These traces indicate periodic colonization of the sediment due to erosional scouring of the tops of dunes. They also indicate temporarily existing humid conditions which were more favourable to various forms of life. These deposits have been assigned to the maximum wetting surface horizon.

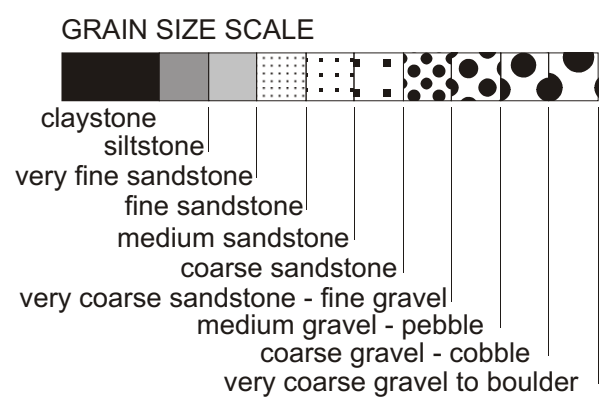

aeolian dune sandstones

aeolian sand sheets

alluvial and fluvial sandstones

SS trace fossils - burrows

Fig. 5. Upper Rotliegend sections (units 6 and 7) section from Pniewy 3 borehole, depth 3556-3582 m 


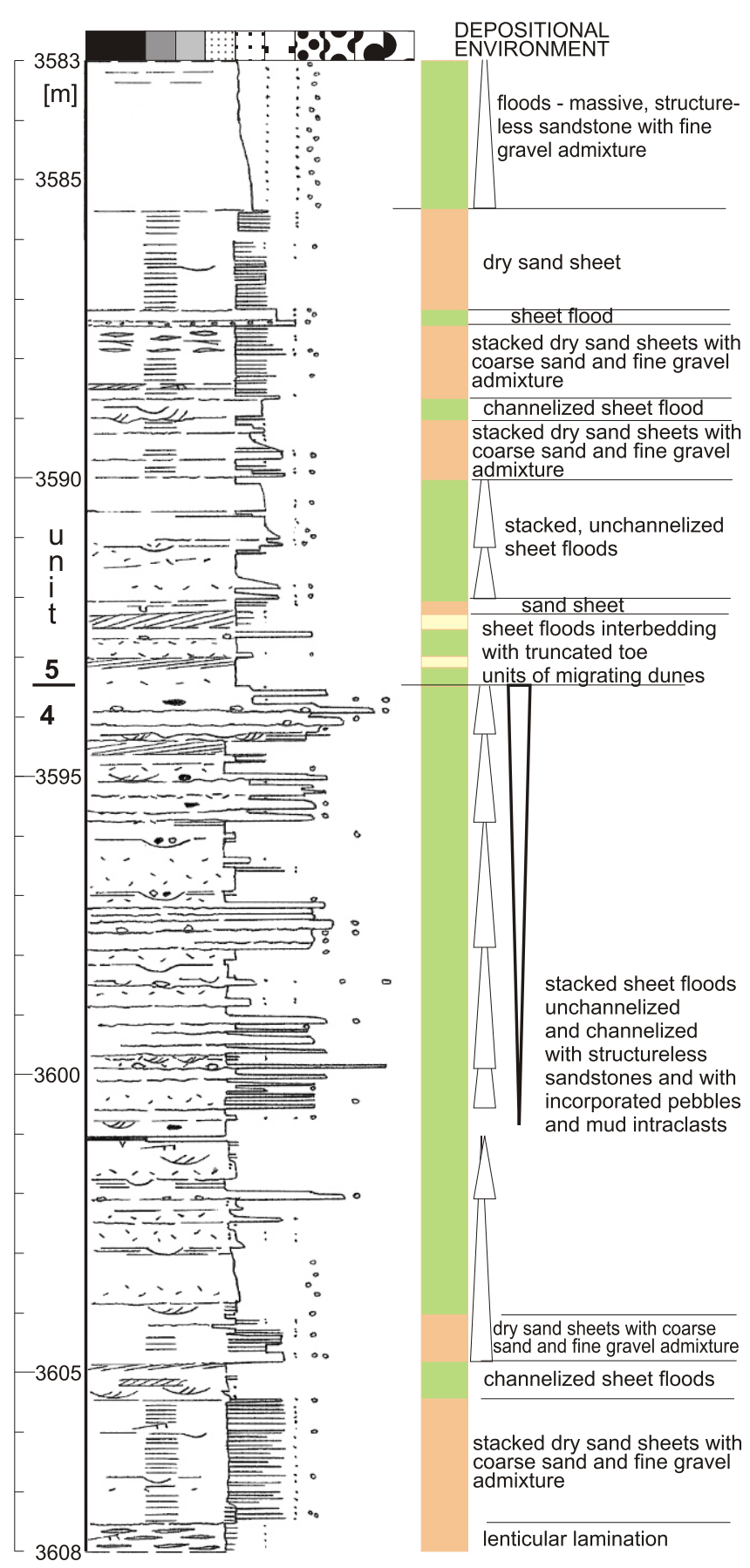

Fig. 6. Upper Rotliegend section (units 4 and 5) from the Pniewy 3 borehole, depth 3583-3608 m

For other explanations see Figure 5

The sedimentological section shown in Figure 13 (see section location and units numbers on Fig. 16) includes three main depositional units (7-9) which formed at the end of Rotliegend deposition in the Pniewy region.

From the bottom upward these are: (1) aeolian complex composed of sand sheets with interbeds of dune deposits; (2) alluvial complex; and (3) another aeolian complex composed of dune sets. The top erosional boundary is related to the Zechstein Sea transgression. The sand sheets are represented by finely laminated, fine-grained sandstones with scattered grains of medium and coarse sand. Coarse sandstone laminae are sporadic. The sand sheets are interbedded with aeolian de- posits composed of preserved parts of erosionally truncated dune base elements. Initial dune base sedimentary units, with low-angle lamination passing upward into lamination with gradually increasing angle, small lamina sets with variable dip angles, and parts of dune elements with high-angle lamination, represented by lamina sets of lee slope, have been distinguished. They reflect dune migration on the surface of sand sheets. No distinct erosional structures are observed within the sand sheet deposits.

Alluvial deposits occur as depositional sequences (fining-upward cycles) with a total thickness of about $4.5 \mathrm{~m}$. These sequences represent a system of channelized, with small current structures, and non-channelized floods and flood sheets, which are associated with the distal alluvial fan. This is evidenced by the presence of coarser clastic material, i.e. pebbles of volcanic rocks.

The overlying rocks are represented by aeolian deposits. These are composed of several sequences of sandstone lamina sets showing variable dips and azimuths, separated by first-order bounding surfaces. There are also second-order bounding surfaces associated with reactivation surfaces. The aeolian sequences are composed of single and complex dunes and locally forming cosets, consisting of erosionally truncated parts of dunes. Sub-horizontal erosional boundaries indicate a complex aeolian form which is a part of a larger structure.

Marginal playa deposits of the analysed interval shown in Figure 14 (see well location in Fig. 2) are characterized by uniform aggradation manifested by sequences of minor fining-upward cycles arranged in higher-order fining-upward cycles. This interval is dominated by medium- and fine-grained sandstones, with interbeds of mudstones and rare claystones in its upper part. A rapid change from aeolian dune and sand sheet depositional environment to marginal playa environment is shown in Figure 3. This change is interpreted as sequence boundary.

The bases of most of the cycles are marked by sharp erosional boundaries. Shallow scours and small current structures, including ripple-mark structures, are frequent. Flaser and lenticular bedding is observed. Irregular contorted lamination and small convolute structures, related to unstable density stratification, have been identified (Fig. 15). Thin sandstone layers with fine intraclasts of clay and mud laminae are visible. Larger intraclasts of laminated sandstone are sporadic. Water-escape structures are also observed sporadically. No desiccation structures have been found. Interbeds of sorted clay or mud deposits are rare. They represent ephemeral standing water periods.

The analysed complex of marginal playa deposits includes eight interbeds of aeolian sandstones composed of parallel aeolian ripple laminae, which represent preserved parts of erosionally truncated lower elements of dunes. The dunes are eroded by playa deposits which overlie the truncated set of aeolian avalanche strata of a dune. In most cases, these are parts of weathered elements of dunes with high-angle lamination. This reflects the stage of dune migration on the playa surface. Rarely, they are initial dune base sedimentary units (stoss slopes?) which begin with low-angle lamination, with a gradually increasing upward angle in the section.

\section{TECTONIC CONTROL ON DEPOSITION}

In the study area, the Poznań Basin (Pokorski, 1988a) is bordered on the west by the Nowy Tomyśl-Lwówek and Gnuszyn tectonic high. This high is devoid of Rotliegend sedimentary rocks. Lower Permian volcanic rocks lie directly under the Zechstein deposit. Lower Rotliegend sedimentary rocks might also be present. Their presence is limited to the hypothetical Lubiatów-Pniewy tectonic graben (cf. Fig. 18). Lower Rotliegend 


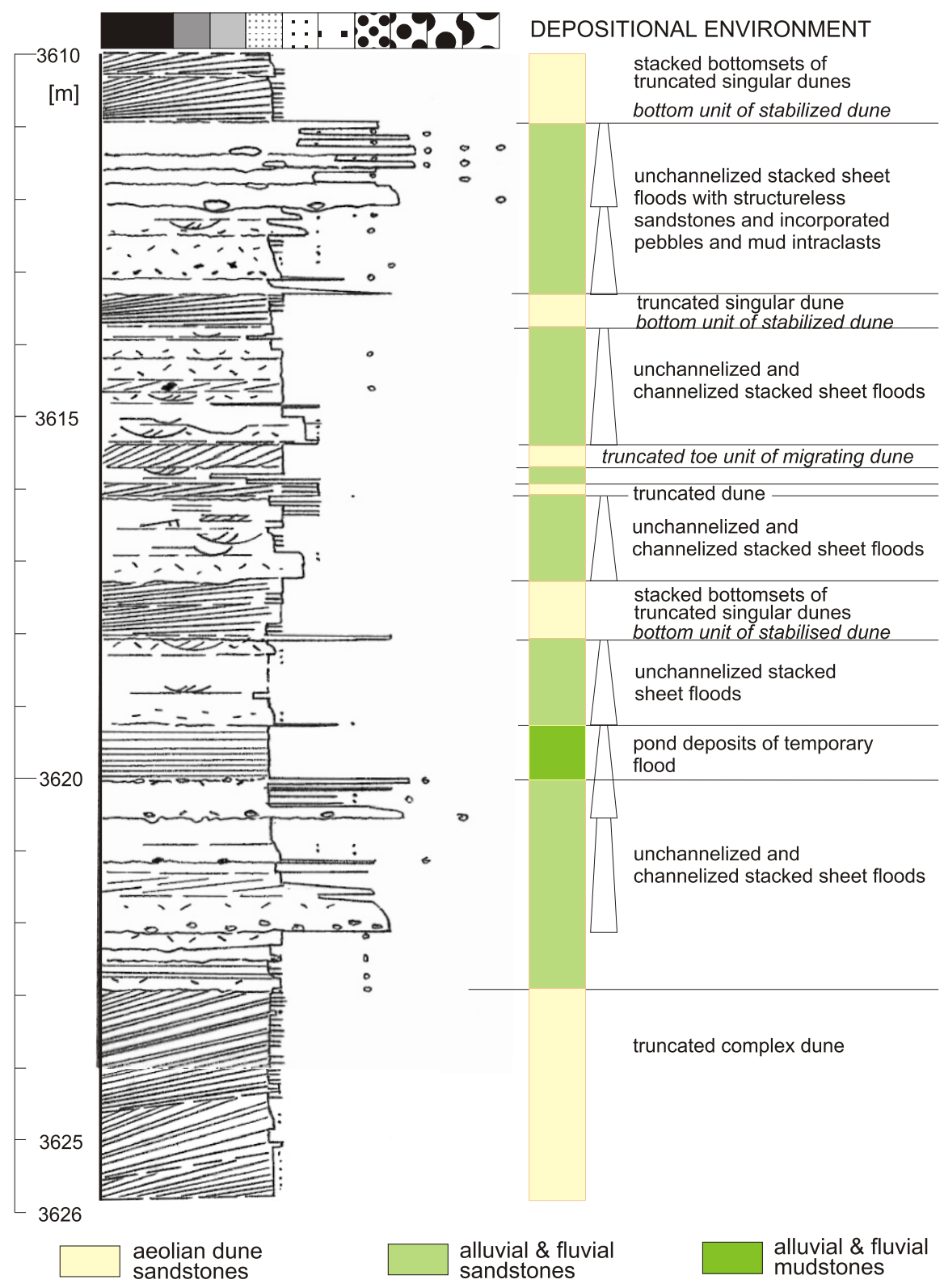

Fig. 7. Upper Rotliegend section (unit 3) from the Pniewy 3 borehole, depth 3610-3626 m

sedimentary rocks also occur in the area located north of the Sokolniki 1 and Kaźmierz 1 boreholes and extend as far as the Obrzycko 1 borehole (Maliszewska et al., 2003; cf. Fig. 18).

It is assumed that an Early Permian tectonic graben of Mężyk-Obrzycko-Golęczewo probably extends in that area, bordered on the north-east by the zone of Poznań-Szamotuły tectonic highs. It is also assumed that, immediately beneath the Zechstein succession on the northwestern prolongation of the elevated Sokolniki-Rokietnica tectonic structure, Lower Carboniferous deposits can occur; and not only Permo-Carboniferous volcanic rocks, as interpreted so far (Fig. 18).

In the northeastern part of the study area there is the Golecczewo-Obrzycko tectonic zone. It is part of the larger, long-lasting Poznań-Szamotuły tectonic system (Dadlez, 1997). Activity in this tectonic zone, during the sedimentation of Upper Rotliegend deposits, significantly affected the thickness of de- posits or resulted in their absence. This zone separated the area into the southwestern part, with a lower subsidence rate, and the northeastern part, with a higher subsidence rate. Within this zone, Upper Rotliegend deposits have a smaller thickness due to the occurrence of syndepositional highs or pre-Zechstein erosion. The latter option is discussed hereafter.

The southern part of the study area is dominated by aeolian deposits that belong to the western part of the Eastern Erg (Kiersnowski, 1997). They immediately overlie Lower Carboniferous rocks or Lower Rotliegend volcanic and sedimentary rocks. In the north of the study area, marginal playa deposits are underlain by Upper Rotliegend aeolian sediments. These represent a northward continuation of the aeolian sheet of the Eastern Erg. These are, in turn, underlain by Lower Rotliegend volcanic and/or sedimentary rocks (Maliszewska et al., 2003; Fig. 18).

The thickness of the Upper Rotliegend deposits is dependent upon the variations in the geological structure and tectonic framework of the basement. In the case of the Pniewy 3 borehole (Fig. 16), the considerable thickness of the deposits (ca. $160 \mathrm{~m}$ ) is related to the occurrence of an Early Permian tectonic graben in the basement. This probably continues toward the west, into the Lubiatów region.

In the Pniewy 2 borehole, the deposits have a thickness of $170 \mathrm{~m}$. This is due to the presence of part of a well-preserved aeolian cover at the top (Fig. 16). This cover is not preserved in the Pniewy 3 borehole.

In turn, a lower thickness of deposits in the Rokietnica 1 borehole (ca. $70 \mathrm{~m}$ ) is associated with the synsedimentary tectonic Rokietnica High (Figs. 4 and 16). In the Obrzycko 3 borehole (ca. $100 \mathrm{~m}$ ), the lower thickness is associated with the Obrzycko High (Fig. 3; cf. Fig. 18).

The Zechstein Sea transgression did not cause significant erosion of the Rotliegend deposits, although it inundated an area of diverse relief. The erosion resulted from the fact that the transgression was rapid and flooded the area without the effect of prior relief levelling (Kiersnowski et al., 2010; cf. D. Peryt et al., 2012).

\section{INTERPRETATION OF DEPOSITIONAL SYSTEMS}

\section{ALLUVIAL DEPOSITIONAL SYSTEM}

The alluvial fans which formed due to erosion of the Nowy Tomyśl-Lwówek and Gnuszyn tectonic highs were developing 

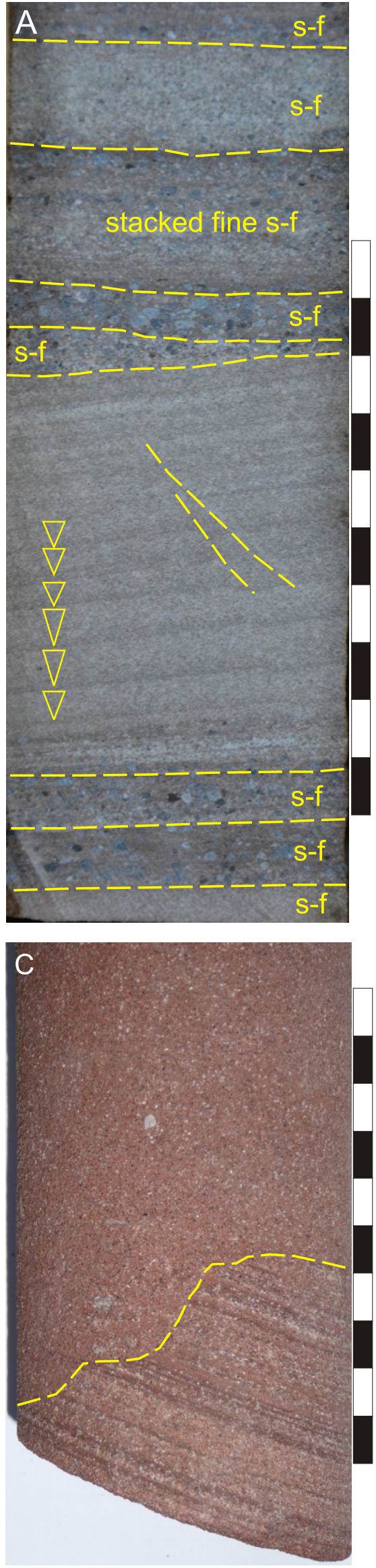
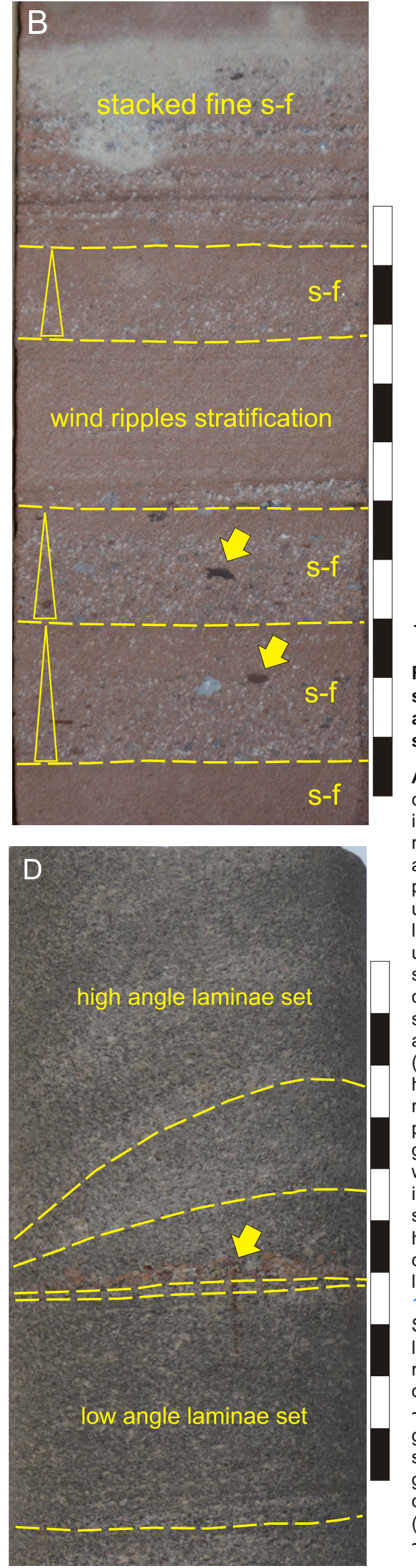

Fig. 8. Core slab photos of stacked, fine sheet flood covers (A, B - flat slab surface) and dune deposits (C, D - core convex surface)

A - in the upper part, a stacked, sheet flood covered dune. Lack of distinct, normal grading (fining-upward) sequences proves a rapid dewatering of sheet flood deposits and/or truncation of the upper, finer grained part. In the middle part, lies a protected dune unit with a well-developed, inverse grading lamina set. The dip angle slightly increasing upward. In the lower part, stacked, small sheet floods occur; Pniewy 4 borehole, depth $3524 \mathrm{~m}$; B - the upper part represents stacked, fine sheet floods reworked by wind and sheet flood arranged as normal grading (fining-upward) microsequences. Planar, horizontal lamination in the central part, represents wind ripple stratification. The lower part represents stacked, sheet floods arranged as repeating, normal grading (fining-upward) microsequences. Note the clay intraclast incorporated into the sheet flood sediment (yellow arrows); Pniewy 4 borehole, depth $\sim 3580 \mathrm{~m}$; $\mathbf{C}$ - this represents dune core deposits with aeolian pin stripe lamination (see Fryberger and Schenk, 1988). The dune is eroded by flood deposits. Steep erosive surface indicates relatively large erosion. Flood deposits are structureless, "massive" sandstone, with admixture of fine gravel grains. Kaźmierz 1 borehole, $\sim 3684 \mathrm{~m}$; $\mathbf{D}$ - the dune is formed by high angle dipping, a thick bottomset of bimodal sands (interbedded fine and medium grained layers). Coarse grains, separated on dune lee side, are integrated at dune toe set (yellow arrow); Kaźmierz 1 borehole, depth $\sim 3626 \mathrm{~m}$ 


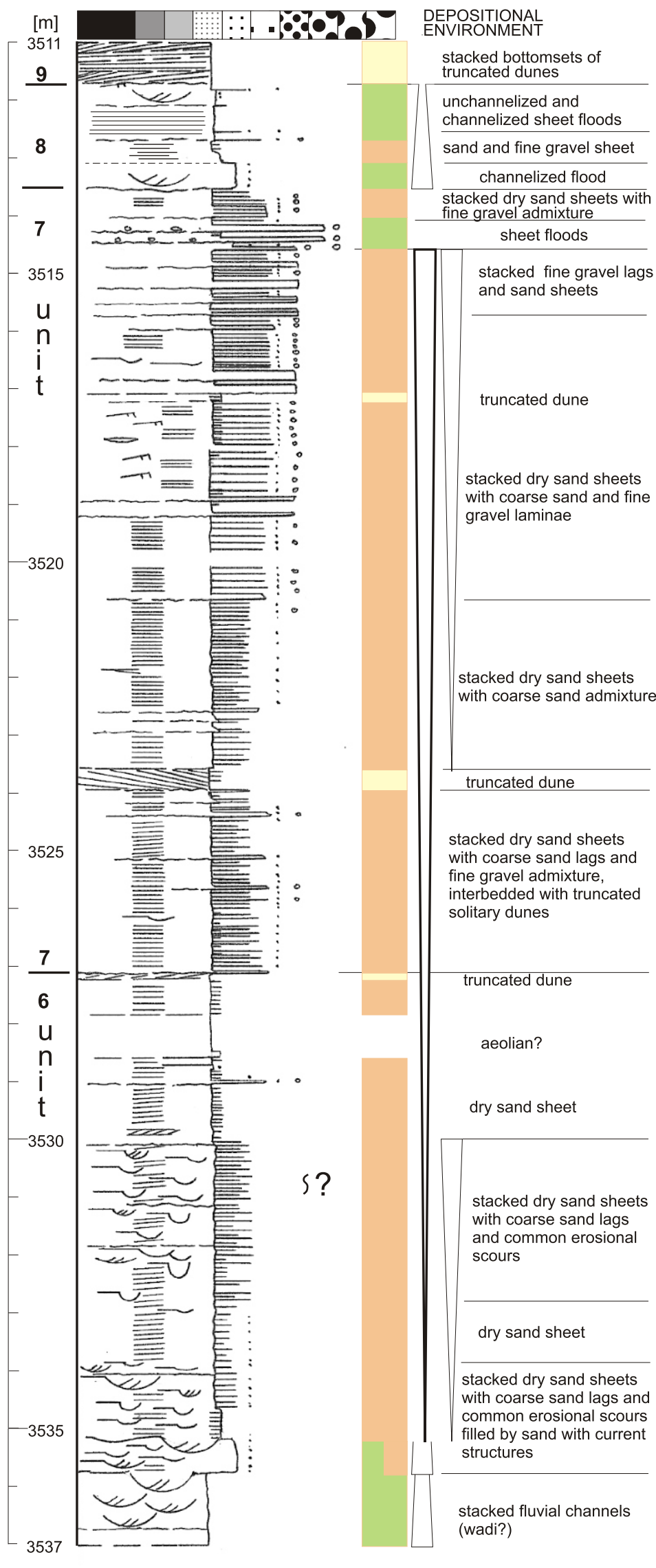

Fig. 9. Upper Rotliegend section (units 6-9) from the Pniewy 2 borehole, depth 3511-3537 m from the west to east. Erosion affected different types of volcanic rocks and clastic deposits of Carboniferous age. These compose the highs in the west, as well as those occurring in the analysed boreholes in the immediate sub-Rotliegend basement.

Sequences of alluvial deposits are particularly visible in the boreholes of Pniewy 1, 2, 3 and 4, and Sokolniki 1 (Figs. 16 and 17), all of which are located closest to the presumed edge of the high. The borehole sections reveal the presence of deposits which represent distal parts of alluvial fans and alluvial plain. The tectonic factor stimulating the reactivation of fault scarps caused the formation of largely aggradational systems of alluvial fans. The climatic factor favoured the development of progradational and retrogradational stacked sequences of alluvial fans. It seems that the climatic factor was more important for the alluvial system development. Alternating deposits, represented by alluvial and aeolian deposition in prevailing humid or arid conditions, were observed in the borehole sections and indicate palaeoclimate fluctuations.

Distribution and redeposition of alluvial deposits occurred in the form of seasonal flows in a confined river system of wadi type, and in the form of overbank, surface sheet floods. The wadi system developed mainly on the low-angle, distal parts of alluvial fans - distributary channels. The alluvial plain was dominated by channelized, with current structures, and non-channelized sheet floods and seasonal small endorheic lakes. Heavy loaded (cohesive), structureless flood deposits and complex channel deposits, with distinct current structures, are a record of rapid, episodic flows.

In the other sections, located at a greater distance from the edge of the high, flood episodes are marked within dune or sand sheet deposits as erosional boundaries. These appear in the form of scours and interbeds.

Alluvial deposits are faced with dune fields developing in a roughly opposite direction. The rate and scale of aggradation of aeolian sediments might have resulted in the stacking of alluvial deposits. Consequently, this might have given rise to an effect of pseudo-progradation of alluvial fan deposits. The alluvial deposits filled the space between the older alluvial fan slope and the opposite slope of the dune field. Their onlapping, or climbing of the dune field slope, might have given it the appearance of a pseudo-progradation signature (see Fig. 26). However, the analysed alluvial sections show a record of fining-upward cycles of various ranks, which indicate sustained aggradation. Lower order, fining-upward cycles of a stair type have been distinguished (Fig. 6). These are characteristic of incompletely developed stacked micro-cycles, where, as the transport energy waned, the change in grain size occurred in steps.

It should be emphasized that the waning or increase in transport energy for the individual depositional episodes takes place in a relatively small area. This is typical of flood and sheet flood deposits. In exceptional cases, small coarsening-upward cycles were observed. These are not directly related to the alluvial fan progradation, but are a record of increasing energy of the succeeding sheet flood. 

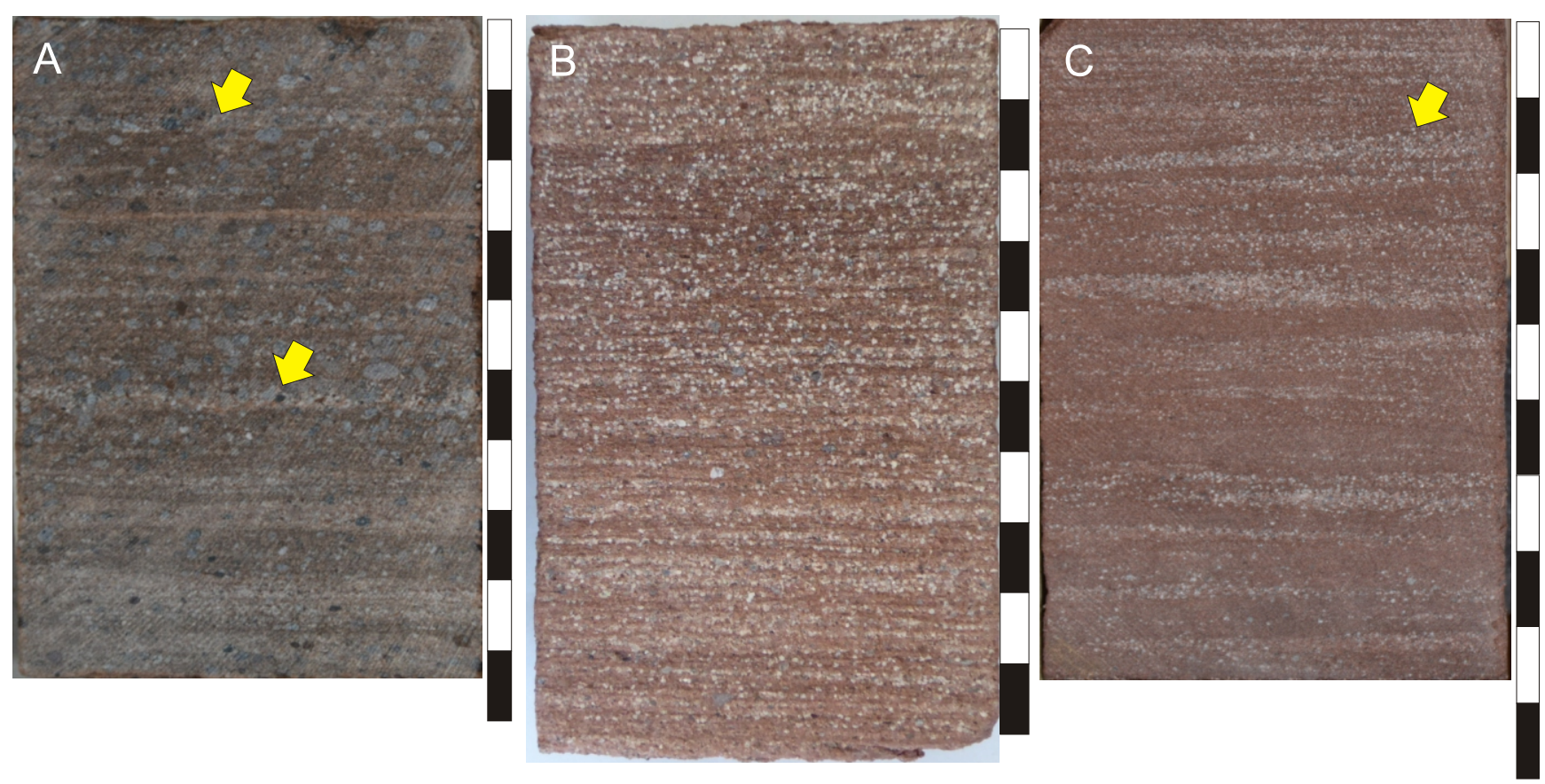

Fig. 10. Core slab photos of sand sheets

A - sand sheet laminae interbedding with very fine gravel (granule) laminae (yellow arrows). The basic framework is composed of irregular, fine, flat lamination and low angle inclined lamination formed by bimodal (fine and very fine) sand grains. Granules form thin laminae, or are dispersed in fine sand. Pniewy 4 borehole, depth interval 3523-3524 m; B - sand sheet (wind ripple lamination) composed of fine sand grains and clay admixture. Very fine, millimetre scale, regular flat lamination with rare, low angle inclined lamination. Medium and coarse sand grains are irregularly dispersed, or form thin laminae. Pniewy 1 borehole, depth $\sim 3621 \mathrm{~m}$; C - sand sheet (wind ripple lamination) composed of fine sand grains with clay admixture. Very fine, millimetre scale, regular flat or inclined lamination. Parts of the inclined laminae were formed in shallow, broad erosional scours. There are also single, poorly visible wind ripples, internal structure (yellow arrow). Pniewy 4 borehole, depth $\sim 3574 \mathrm{~m}$

The sequences of flood and channel deposits contain various sizes mud intraclasts. Large intraclasts were sporadically found in the Pniewy 3 borehole (3583-3608 m; Fig. 6) because there is a fluvial drainage axis in this area. Large intraclasts were also found in the Pniewy 1 borehole at a depth of $3634 \mathrm{~m}$.

Small mud intraclasts frequently occur in sheet flood deposits. This is characteristic of the dominance of a scattered system of sediment distribution, mainly in the form of the so-called flash floods, which result in the formation of thin clay and mud layers.

\section{AEOLIAN DEPOSITIONAL SYSTEM}

Dune, interdune and marginal (extra dune) deposits have been identified in the Eastern Erg (Fig. 1). A specific feature of marginal aeolian deposits is a significant development of sand and sand-gravel sheets. These are found on a scale unknown in other parts of the Rotliegend Basin (Figs. 5 and 9). In the study area, dune fields had migrated from the east, northeast and south-east, in accordance with the direction of prevailing winds (Kiersnowski, 2013), opposite of the direction of prograding alluvial deposits (Fig. 24).

Could the interactions between these depositional systems be the cause of development of sand and sand-gravel sheets? An attempt to answer this question is related to the broader issue which concerns the sedimentation of large-scale sand sheets in marginal zones of ergs (Kocurek and Nielson, 1986; Chan et al., 1992; Al-Masrahy and Mountney, 2015).

Al-Masrahy and Mountney (2015) examined 130 areas from 60 modern deserts worldwide. They found only 10 areas of sand sheet formation, and the alluvial or fluvial sedimentation which took place, in the marginal zones of ergs. However, the case of the modern extensive sand sheet of Selima, at the borderland of Egypt and Sudan, proves that sand sheets can occur independently (Breed et al., 1987).

Sand sheet and sand-gravel sheet sediments alternate with dune sequences. Dune deposits are separated by numerous erosional boundaries of various ranks. These are preserved elements of single dunes and more complex dunes.

To the east and south of the study region, into the Eastern Erg area, there are stacked dune deposits of the considerable thickness of $>500 \mathrm{~m}$, with preserved thicker elements of single, either transverse or barchanoid, dunes. These deposits contain single interbeds of sand sheets. A small part of these sand sheets is observed in the upper units of the profiles from some of the boreholes within the Southern Erg (Silesian-Zielona Góra Rotliegend Basin; Poszytek, 2014).

\section{MARGINAL PLAYA DEPOSITIONAL SYSTEM}

Varying extents of the marginal playa are observed only in the northern part of the study area. The playa almost permanently accompanied aeolian fields. It gradually prograded into tectonic depressions, such as the Obrzycko Bay, and dominated successively over a larger area (Figs. 18-24).

Its southern extent was consistently limited by a number of tectonic highs developed along the Sokolniki-Kaźmierz-Rokietnica line. Fluctuations in the playa extent might indicate a relationship with cyclic climate changes (dry-wet sequences as climatic cycles). Numerous interbeds with aeolian deposits prove a progradation of dunes into the playa area during arid periods, 


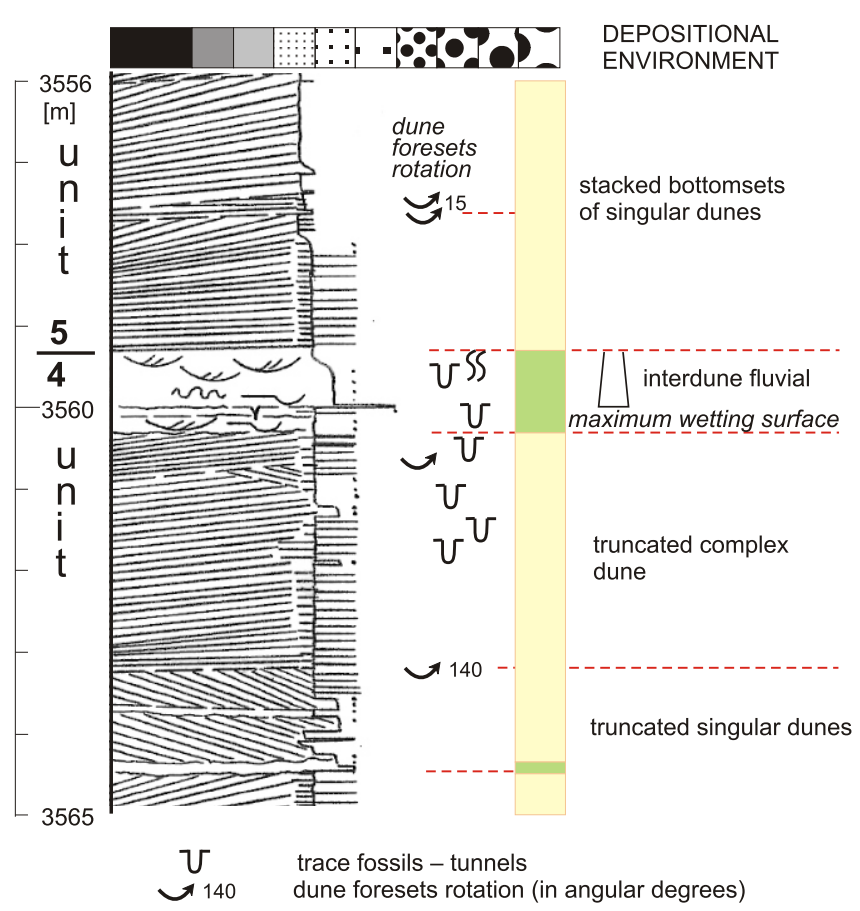

Fig. 11. Upper Rotliegend section (units 4 and 5 ) from the Pniewy 2 borehole, depth 3556-3565 m

and vice versa: progradation of playa sediments (playa incursions) onto aeolian sediments during humid periods (Figs. 3 and 14).

The boundaries between these sediments are erosional in nature. In the study area, there is a marginal playa dominated by fine-grained sandstones and mudstones deposited as a number of minor fining-upward cycles. In the analysed sections, for example in the Objezierze IG 1 borehole (Fig. 14), the following sedimentary structures have been identified: flaser and ripple lamination, buried adhesion marks, water escape structures, and minor density-driven deformation of sediment (micro-convolutions) which are characteristic of fine-grained deposits accumulated in a humid environment with periods of surface drying (Fig. 15).

\section{CYCLES (DEPOSITIONAL UNITS) AND CYCLIC DEPOSITION}

In the Pniewy-Objezierze region, the Upper Rotliegend deposits consist of a number of arbitrarily distinguished depositional complexes (units). These complexes are marked with numbers ordered from base to top. Distinguishing these depositional complexes was dictated by the need to group the frequent changes in sedimentary environments in the analysed borehole sections, and by the attempt to arrange them spatially (Figs. 16 and 17).

The Upper Rotliegend sediments contain a large number of erosional boundaries and gaps of different ranks and sizes. To separate the depositional complexes, major erosional boundaries, probably of regional extent, were arbitrarily chosen. In the aeolian deposits, these boundaries might be associated with deflation surfaces related to the stabilization of groundwater levels (Loope, 1985; Kocurek, 1988). In the marginal playa deposits, the boundaries might be correlated to transgressive surfaces
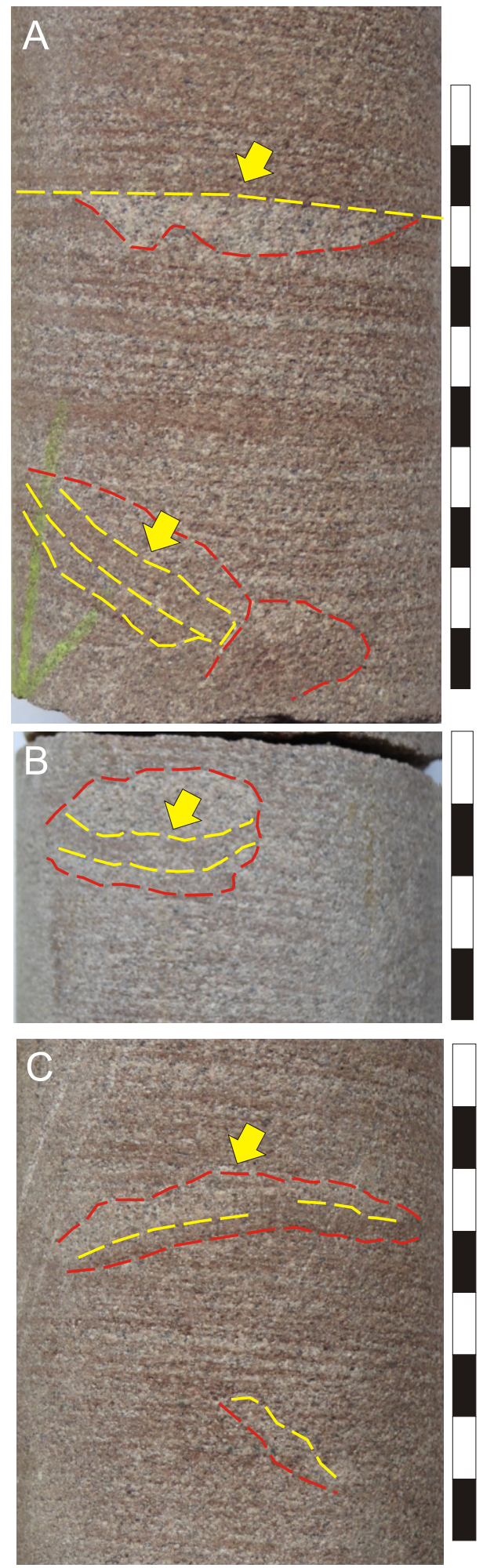

Fig. 12. Core photos of sand sheet (A, B, C - core convex surface)

Sand sheet composed of low angle sets of fine, millimetre scale, regular parallel lamination, horizontal or slightly inclined, with animal burrows; $\mathbf{A}$ - a large burrow, in the form of a tunnel with a collapsed ceiling. In the core's upper part, there are remnants of a former burrow, truncated by erosion surface (yellow arrow). In the core's lower part, lies a burrow with a detached piece of laminated rock (yellow arrow); B, C - both show a large burrow, in the form of a tunnel with a collapsed ceiling (yellow arrow). In B, collapsed sand forms a burrow floor. Kaźmierz 1 borehole; core samples are from a depth of 3640-3641 m 


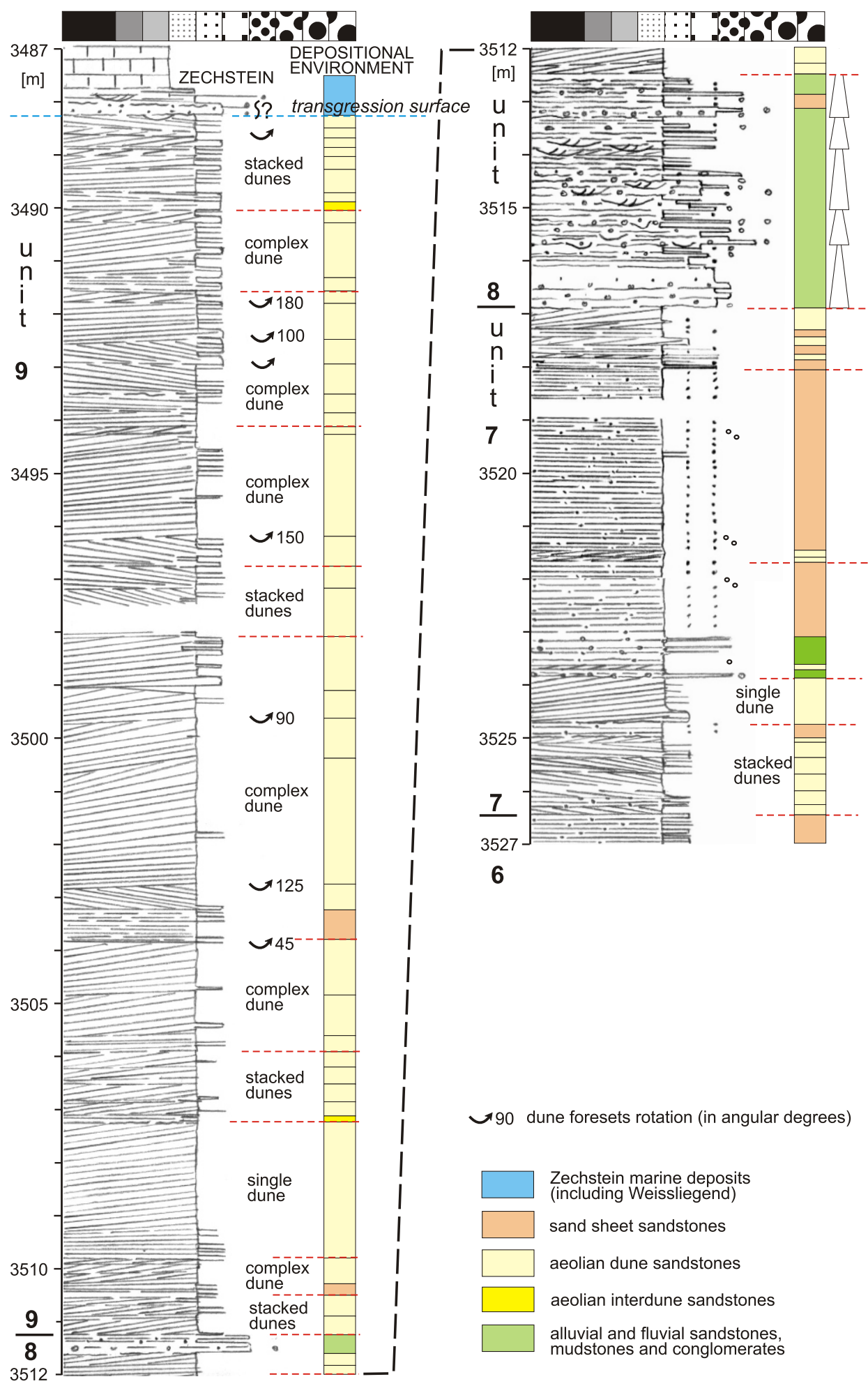

Fig. 13. Upper Rotliegend section (units 7-9) from the Pniewy 4 borehole, depth 3487-3512 $\mathrm{m}$ and 3512-3527 m

which developed during playa expansion (Sweet, 1999). Time gaps related to the boundaries and the scale of erosion are difficult to estimate. Regional erosional boundaries might be highly dependent on the tectonic factor, e.g. uplift during sedimentation. The identification of the depositional units was also based on the interpretation of the sedimentological record in palaeoclimatic terms. Ultimately, nine depositional complexes have been proposed (Figs. 16 and 17), representing most of, or the whole of the Upper Rotliegend Noteć Formation (Pokorski, 1988b).

We do not have enough information about the type of deposits in the deepest parts of the Pniewy region. Therefore, the incompletely cored first depositional unit is subdivided into two 


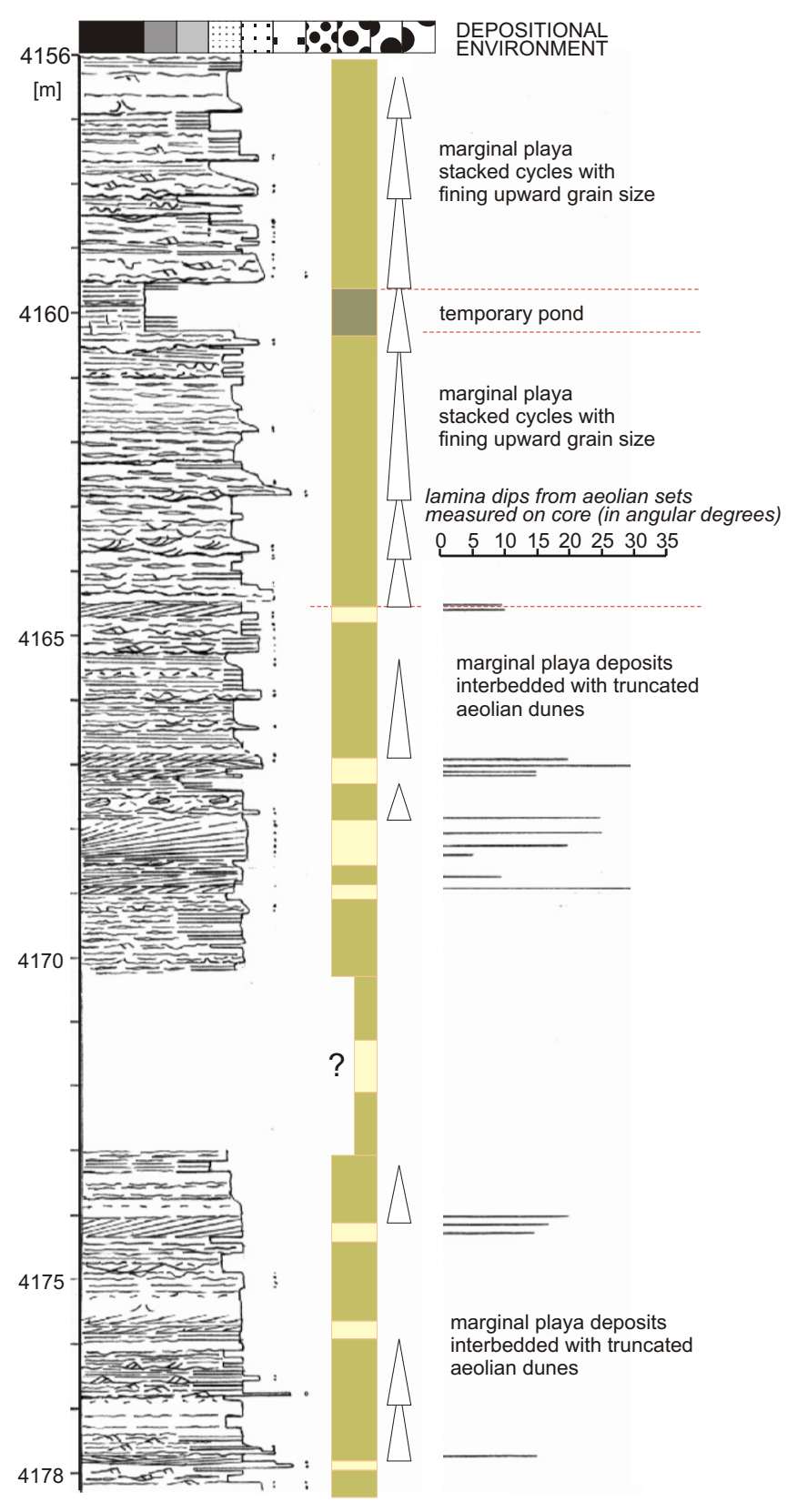

aeolian dune sandstones

playa mudstones and fine sandstones

claystones

Fig. 14. Upper Rotliegend section (units 7-8) from the Objezierze IG 1 borehole, depth 4156-4178.2 m

subunits, $1 \mathrm{~A}$ and $1 \mathrm{~B}$. Toward the top, good and very good coring enabled detailed sedimentological analysis and identification of the remaining depositional units.

Similar subdivisions were used for the Upper Rotliegend deposits which are correlated lithostratigraphically with the Noteć Formation (Gast et al., 2010), from the western part of the Southern Permian Basin (George and Berry, 1997; Sweet, 1999). Here, sequences clearly controlled by the fluctuations of Late Permian palaeoclimate have been distinguished.
In the Dutch-British Basin, Yang and Nio (1993) identified 12 sequences which are grouped into five super-sequences. Van Oijk et al. (2011) provided a summary of previous analyses of subdivision into sequences, and presented six sequences combining the criteria of palaeoclimate-based and sequence stratigraphy methods. In turn, Minervini et al. (2011) presented a sequence subdivision which was an attempt to combine the sequences from the Dutch-British area with the more central, German part of the Rotliegend Basin. As a result, those authors distinguished 16 depositional cycles grouped into five super-cycles, and correlated these units with the German lithostratigraphic formations of Dethlingen and Hannover. These formations are subdivided, in the North German Basin, into 14 members (depositional cycles; Schröder et al., 1995; Fig. 26).

In turn, in the Polish Upper Rotliegend Basin, the Noteć Formation is subdivided, in the northern Pomeranian part of the basin, into three depositional cycles (Kiersnowski and Buniak, 2006), and in the southern part, the Silesian Basin, into nine depositional sequences (Kiersnowski, 2015).

Depositional Units 1A and 1B. This is the first Upper Rotliegend sedimentary complex developed on the older basement. The complex can attain a thickness of $50 \mathrm{~m}$ and is represented mainly by aeolian and alluvial facies (Fig. 18). Borehole sections containing deposits of this sedimentary complex are illustrated in Figures 16 and 17. It begins with coarse-clastic deposits of a weathering mantle and an alluvial sheet. They show a small thickness, or the deposits are missing. They are overlain by a complex of aeolian and alluvial deposits. The aeolian deposits consist of minor dune sequences composed of erosionally truncated single or compound dunes and frequent sequences of sand sheet deposits. The lack of distinct interdune deposits indicates recurrent episodes of accretion and erosion of dunes and rare periods of their stabilization.

In the Pniewy 3 borehole, interbeds of sand sheets are very frequent and dominated by low-angle, flat parallel lamination (Figs. 5 and 7). The occurrence of sand sheets and sporadic sand-gravel sheets at the early stage of sedimentation indicates that, in the Pniewy region, suitable conditions determining this type of deposition had existed since the beginning of the sedimentary cover development. Aeolian deposits appeared rapidly, pointing to a climate change which enabled mobilization of aeolian transport. Dunes were developed in geomorphic-tectonic depressions whose shape and extent probably reflect tectonic structures of the Variscan Externides.

Alluvial deposits are represented by sheet flood sequences as well as by deposits of massive floods and fluvial channels. Their development is interpreted as being a result of the existence of a geomorphic scarp running in the west, along which deposition of alluvial fans took place.

The complex is terminated by a selected erosional boundary.

Depositional Unit 2. The second Rotliegend sedimentary complex is represented predominantly by aeolian deposits of dunes and sand sheets, from 10 to $30 \mathrm{~m}$ in thickness. These deposits rest upon the older depositional complex 1B, or directly on the older basement, indicating their progradational nature and development of aeolian covers (Fig. 19). Borehole sections containing deposits of this depositional complex are presented in Figures 16 and 17.

Aeolian deposits are composed of dune sequences practically devoid of interdune deposits, e.g. sensu damp or dry interdune developed between dunes. Sand sheets, which are observed in the Objezierze IG 1 borehole, were developed partly in humid conditions which might reflect the effect of marginal playa, and they represent the boundaries of individual ergs. In the borehole sections, we can observe locally compound dunes, with preserved single units, having a thickness of $10 \mathrm{~m}$. In some 
sections with reduced thickness of Rotliegend deposits, interbeds of sand sheets, dominated by low-angle flat parallel lamination, have been distinguished.

There was a development of aeolian deposits, which gradually blurred the pre-existing structural pattern of the older basement.

Alluvial deposits are subordinate; these are sheet floods in the form of interbeds of aeolian deposits. This depositional complex is terminated by an erosional boundary, which can be related to a climate change.

Depositional Unit 3. The third Rotliegend depositional unit is represented by alternating alluvial and aeolian deposits: dune, interdune and sand sheet deposits having a thickness of 10-20 m. Borehole sections with this depositional unit are presented in Figures 16 and 17.

Sedimentary environments of this depositional complex show a decreasing extent of the aeolian cover in favour of alluvial deposits (Fig. 20). Thickness of the alluvial deposits depends on the development and extent of distal parts of alluvial fans. The alluvial deposits are represented by sequences of flood sheets (non-channelized and channelized) and perennial massive floods, associated with the wadi depositional system. The material composing the wadi deposits represents washed-out aeolian sandstones and deposits from a more distant source area. The wadi deposits usually do not form a continuous alluvial sheet, but rather concentrate in places where fluvial drainage zones can develop.

Aeolian deposits, of relatively small thickness, are represented by parts of erosionally truncated dunes separated by sheet flood deposits. There are numerous sand sheets having a thickness of $4 \mathrm{~m}$. Some of the sand sheets are defined as sand-gravel sheets (fine granules). There is one case, in the Sokolniki 1 borehole, with a 5-6 $\mathrm{m}$ thick sand sheet, which shows low-angle, flat parallel lamination which might indicate the presence of zibar-type aeolian features (cf. Fig. 29).

The characteristic features of this complex are deposits of ephemeral ponds, and horizons with preserved bioturbation and assumed traces of plant roots (possibly palaeosol). The occurrence of such structures can be related to a period of more humid climate and can be correlated with one of the periods of playa expansion. If so, it would be a regional correlation horizon referred to as the maximum wetting surface.

This complex is terminated by a selected erosional boundary.

Depositional Unit 4. The fourth Rotliegend depositional unit is represented by sets of alluvial and aeolian deposits: flat
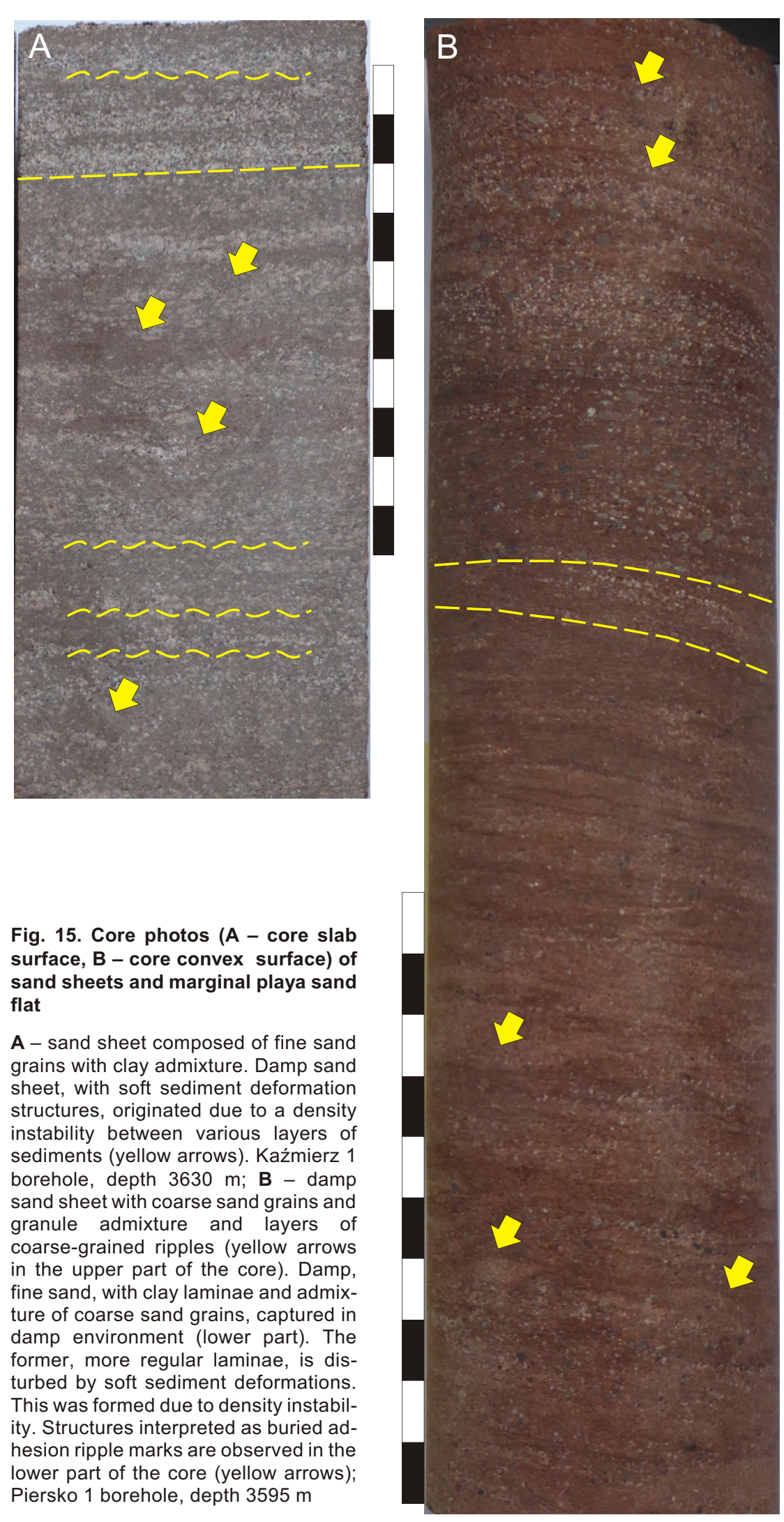

Fig. 15. Core photos (A - core slab surface, $B$ - core convex surface) of sand sheets and marginal playa sand

A - sand sheet composed of fine sand grains with clay admixture. Damp sand sheet, with soft sediment deformation structures, originated due to a density instability between various layers of sediments (yellow arrows). Kaźmierz 1 borehole, depth $3630 \mathrm{~m}$; B - damp sand sheet with coarse sand grains and granule admixture and layers of coarse-grained ripples (yellow arrows in the upper part of the core). Damp, fine sand, with clay laminae and admixture of coarse sand grains, captured in damp environment (lower part). The former, more regular laminae, is disturbed by soft sediment deformations. This was formed due to density instability. Structures interpreted as buried adhesion ripple marks are observed in the lower part of the core (yellow arrows); Piersko 1 borehole, depth $3595 \mathrm{~m}$

dunes and sand sheets with a thickness of 10-20 m (Fig. 21) Borehole sections containing deposits of this complex are presented in Figures 16 and 17.

Aeolian deposits are represented by parts of erosionally truncated dunes separated by sheet flood or sand sheet depos- 


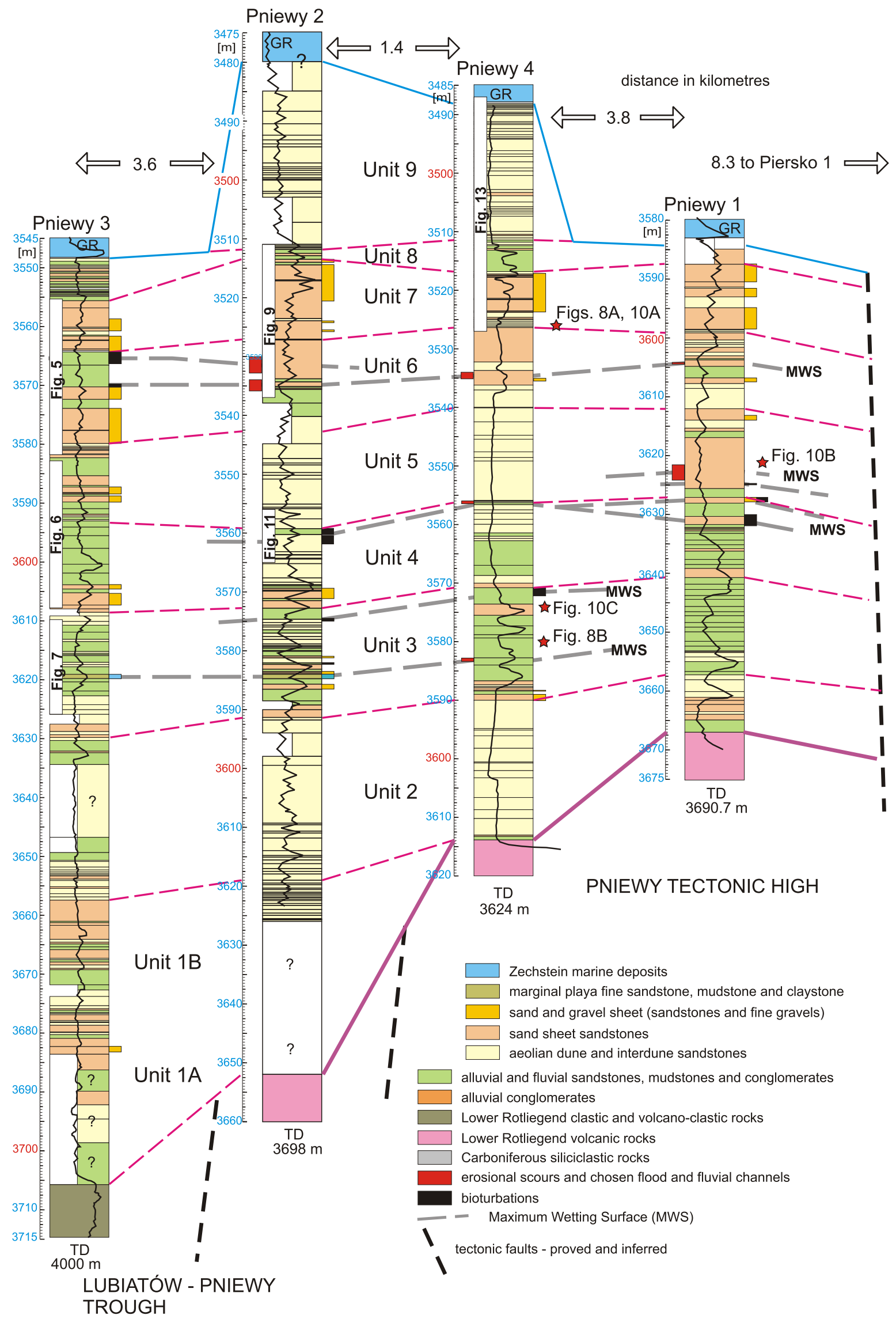

Fig. 16. Lithofacies profiles of the boreholes: Pniewy 3, Pniewy 2, Pniewy 4 and Pniewy, 1 and their correlation 


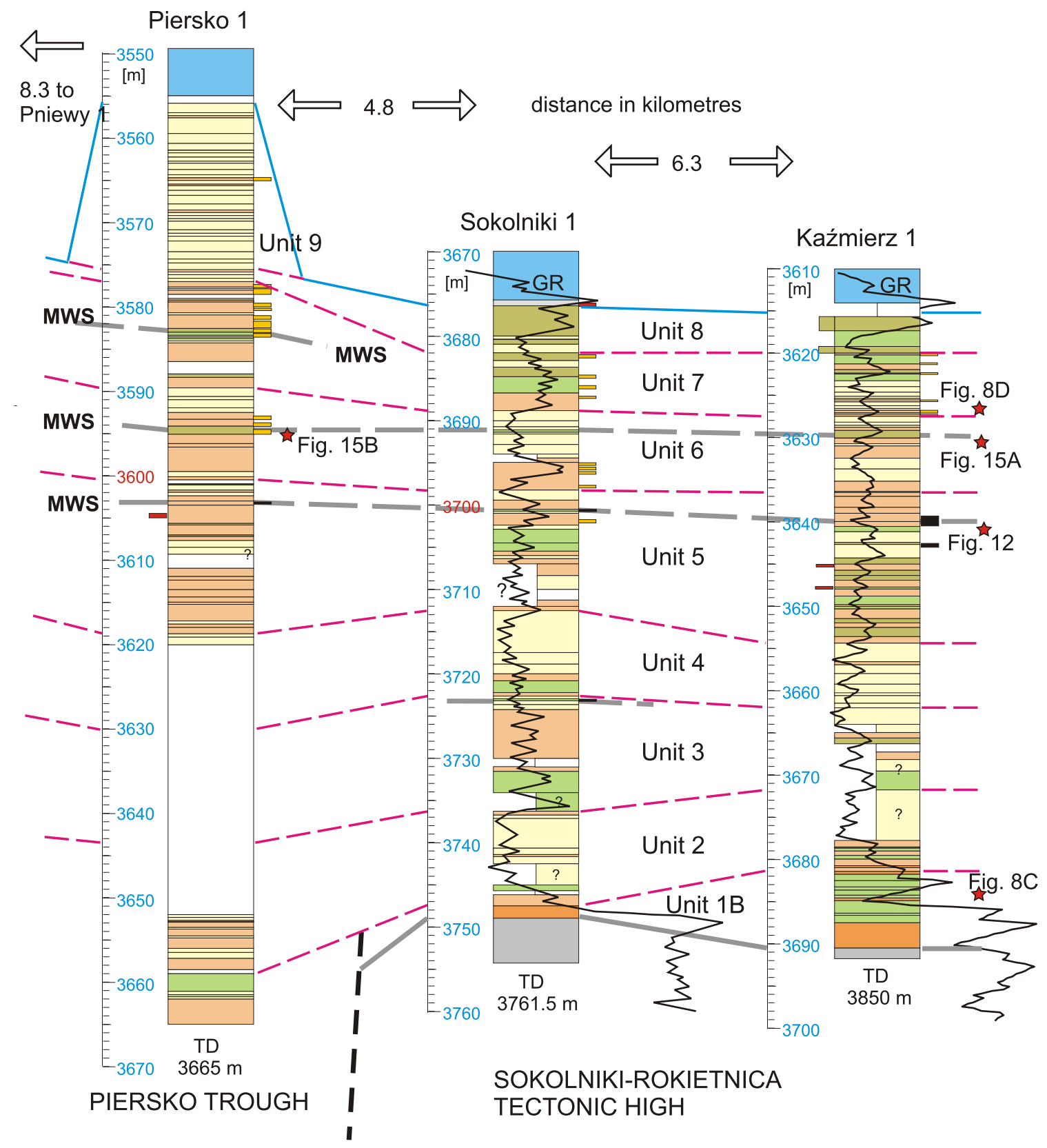

Fig. 17. Upper Rotliegend sections of the boreholes: Piersko 1, Sokolniki 1 and Kaźmierz 1, and their correlation

Explanations are given in Figure 16

its. These are compound dunes which consist of sets of laminae of fine- and medium-grained sandstones, whose dip azimuths are highly variable, which is a characteristic feature of barchanoidal or longitudinal dunes.

The sand sheets have a maximum thickness of $3 \mathrm{~m}$. Some of the sand sheets are defined as sand-gravel sheets (fine-grained gravel - granules).

The aeolian deposits are widespread toward the north and northwest. The northward limit of the aeolian deposits, and their relationship with the playa deposits, are not known. The occurrence of sand sheets in the area of the Obrzycko 3 borehole (Fig. 3 ) indicates that the region was in the northwestern neighbourhood of the Eastern Erg, or might belong to the Eastern Erg area.
The alluvial deposits are represented by distal parts of alluvial fans and alluvial plain. These are sequences of sheet floods, both non-channelized and channelized, and periodic massive floods associated with the wadi depositional system.

The relatively small thickness of individual interbeds of alluvial deposits could be related to their greater distance from source areas and/or to a poorer development of alluvial fans.

The characteristic feature of this depositional complex is bioturbation horizons, visible in some sections, which prove the appearance of living organisms and sediment wetting. Like in depositional sequence 3 , the occurrence of such structures may be associated with a more humid climate and with the formation of a correlative level of maximum wetting surface type (Fig. 11).

This complex is terminated by a selected erosional boundary. 


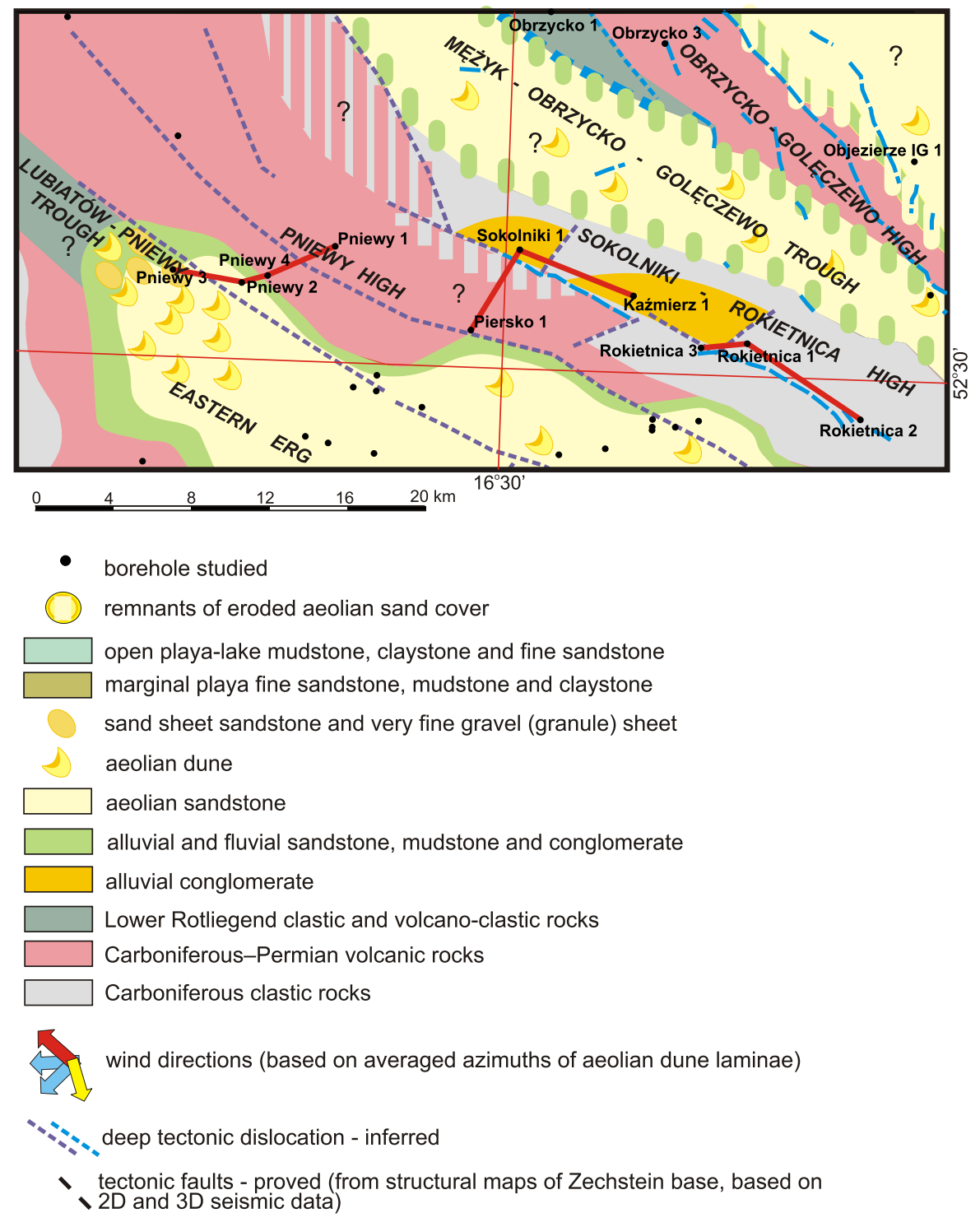

Fig. 18. Palaeogeographic-facies map of the study area (depositional units $1 \mathrm{~A}$ and 1B)

Depositional Unit 5. The fifth Rotliegend depositional complex is represented mainly by aeolian deposits of dunes and sand sheets, and by minor alternating alluvial deposits. The whole complex has a thickness of 15-20 m with a maximum of $40 \mathrm{~m}$ in the area of the Objezierze IG 1 borehole (Fig. 22). Borehole sections containing deposits of this complex are presented in Figures 16 and 17.

The aeolian deposits are represented by parts of erosionally truncated single and compound dunes. In some sections, the dune deposits alternate with sand sheets. Stacked sand sheets have a thickness of $8.5 \mathrm{~m}$ (Pniewy 1), but in most cases (e.g., Fig. 10B), the thickness of the sand sheets is up to $3 \mathrm{~m}$. Sand-gravel sheets (granule-size grains) are observed sporadically. In some sections, the sand sheets show traces of erosional scours that are probably evidence of episodic rainfalls that strongly manifested themselves in depositional sequences of dry climate. The occurrence of sand sheets in the Obrzycko 1 and 3 boreholes (Fig. 3) indicates the widespread extent of this depositional system; and that the Obrzycko region was also a part of the northwestern zone of the Eastern Erg.
In the Piersko 1 borehole, there are sand sheets with low-angle, flat-parallel lamination that can suggest the presence of aeolian features of zibar type (see discussion below).

The aeolian deposits are widespread toward the north and northwest. The northward limit of the aeolian deposits and their relationship with the playa deposits are not known. The alluvial deposits are represented by distal parts of alluvial fans and alluvial plain. These are sequences of sheet floods (non-channelized and channelized), and periodic massive structureless floods associated with the wadi depositional system. Deposits found in the Kaźmierz 1 borehole (Fig. 15A) reveal signs of fluctuations of marginal playa, preserved as repetitive, characteristically thin interbeds of deposits, pointing to its maximum southern limit.

The distinguishing features of this depositional complex are levels with bioturbation and large animal burrows, which are visible in some borehole sections. These are evidence of sediment wetting and the appearance of organisms. The occurrence of structures of organic origin and scours within the sand sheets may be related to a period of more humid climate and the formation of a correlative horizon of maximum wetting surface type.

This complex is terminated by a selected erosional boundary.

Depositional Unit 6. The sixth depositional complex is represented by aeolian deposits of dunes and sand sheets and by minor alluvial deposits. The whole complex has a thickness of $15 \mathrm{~m}$ (Fig. 23). Borehole sections containing this depositional complex are presented in Figures 16 and 17.

The analysed sections are dominated by stacked sand and sand-gravel sheets having a thickness of $10 \mathrm{~m}$ (e.g., in the Pniewy 2 borehole; Fig. 9). However, in most cases, the sand sheets are from 2 to $6 \mathrm{~m}$ in thickness. The characteristic feature of this depositional complex is sand-gravel sheets (granule-size grains). In some sections, the sand sheets show traces of erosional scours. Some sections contain thin interbeds of aeolian sandstones, represented by parts of erosionally truncated single dunes. In the Kaźmierz 1 and Piersko 1 boreholes, there are traces of fluctuations of marginal playa extension, preserved as characteristic, recurring thin interbeds of deposits, pointing to its maximum southern limit (Fig. 17). Some sections show scour levels within the sand sheets and structures of organic origin (bioturbation). This is interpreted as being the result of climate wetting and the formation of a correlative horizon of maximum wetting surface type.

This complex is terminated by a selected erosional boundary. 
Depositional Unit 7. The seventh depositional complex is represented by aeolian deposits: predominantly sand and sand-gravel sheets, with minor dune deposits, and subordinate alluvial and marginal playa deposits. The whole complex has a thickness from 5 to $>10 \mathrm{~m}$ (Fig. 24). Borehole sections containing deposits of this depositional complex are presented in Figures 16 and 17.

The analysed sections are dominated by stacked sand-gravel sheets (granule-size grains) reaching a thickness of $10 \mathrm{~m}$ (e.g., in the Pniewy 2 borehole; Fig. 9). However, the maximum thickness of most sand sheets varies from 2 to $6 \mathrm{~m}$. The characteristic feature of this depositional complex is sand-gravel (granule) sheets, which are especially frequent at the top of the complex. This commonness of sand sheet occurrences was the reason for the name Pniewy Sand-Sheet (Fig. 24). Some sections contain thin interbeds of aeolian sandstones, represented by parts of erosionally truncated single dunes.

In the Piersko 1, Sokolniki 1 and Kaźmierz 1 boreholes, there are multiple thin interbeds of marginal playa deposits (Fig. 17). The interbeds are a record of the maximum southern limits of the playa, and they reflect its interaction with aeolian and alluvial deposits. The fluctuations in the playa limits were probably a response to subtle climate changes.

This complex is terminated by a selected erosional boundary.

Depositional Unit 8. The eighth depositional complex is represented by alluvial deposits with thin interbeds of dune, sand sheet and marginal playa deposits. Borehole sections containing deposits of this depositional complex are presented in Figures 16 and 17.

Playa deposits occur only in the northern part of the study area (Sokolniki 1 and Kaźmierz 1 boreholes). Here, they reach a thickness from $2 \mathrm{~m}$ at the edge of the playa, to $>20 \mathrm{~m}$ in the more distant, northern zone (Obrzycko 1 and 3, Objezierze IG 1 and Golęczewo 1 boreholes). Analysis of the variability of the playa deposits indicates its progradational nature, suggesting expansion of the playa toward the south (Fig. 24).

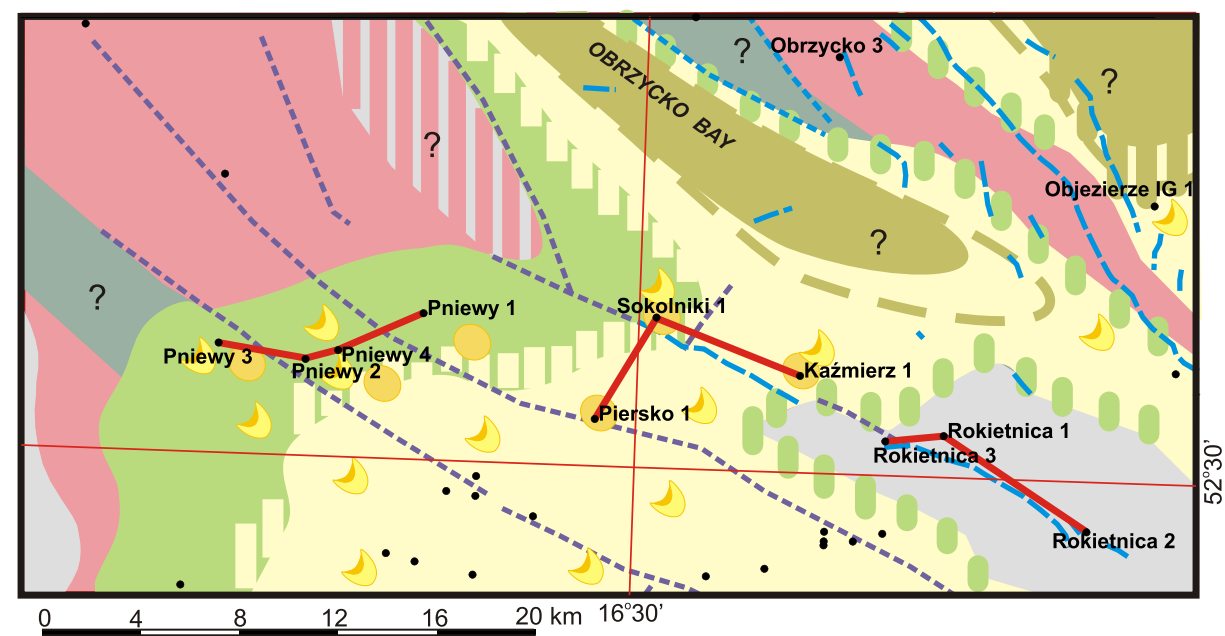

Fig. 19. Palaeogeographic-facies map of the study area (depositional unit 2)

For explanations see Figure 18

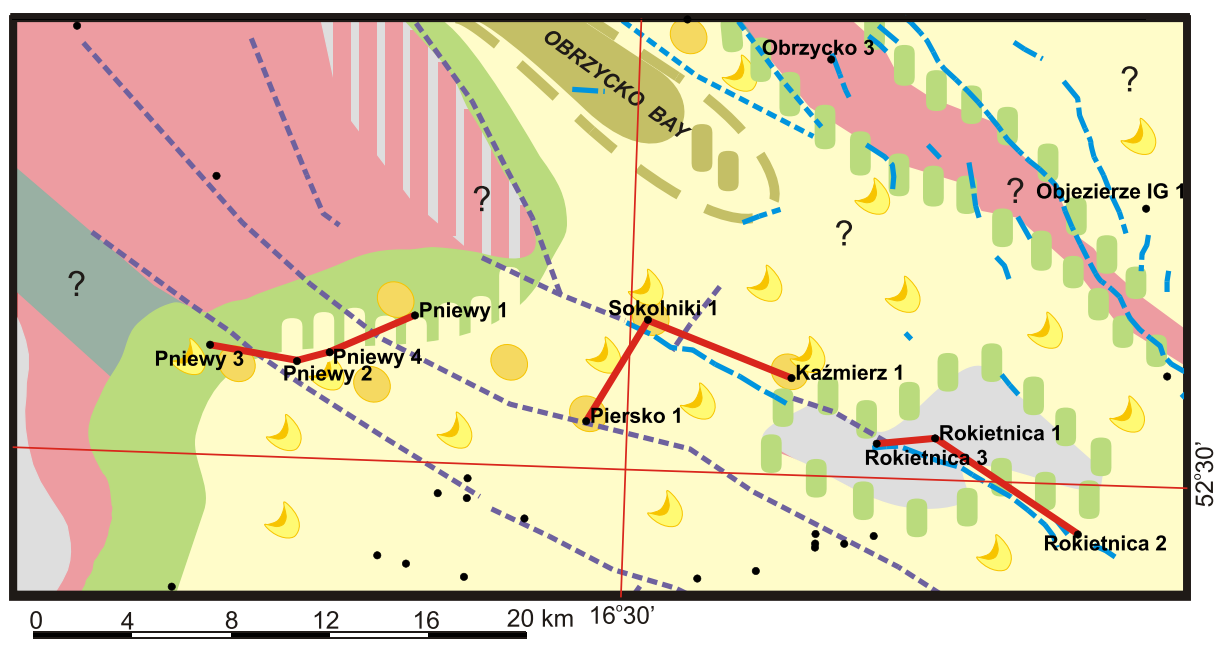

Fig. 20. Palaeogeographic-facies map of the study area (depositional unit 3)

For explanations see Figure 18

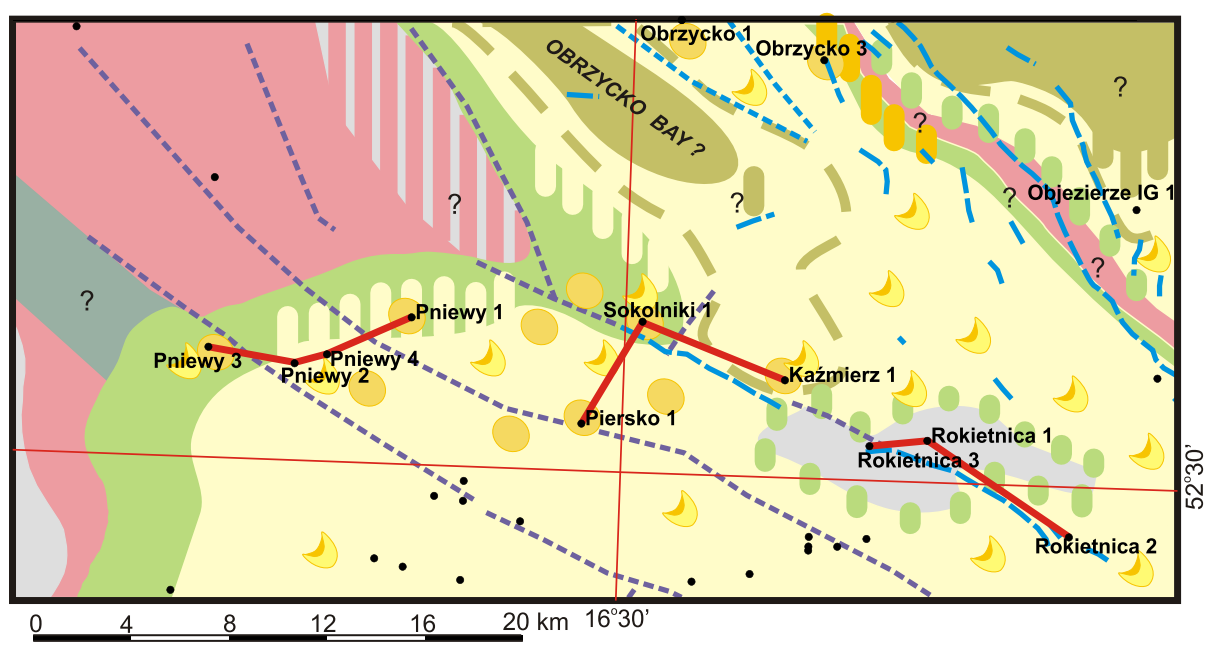

Fig. 21. Palaeogeographic-facies map of the study area (depositional unit 4)

For explanations see Figure 18 


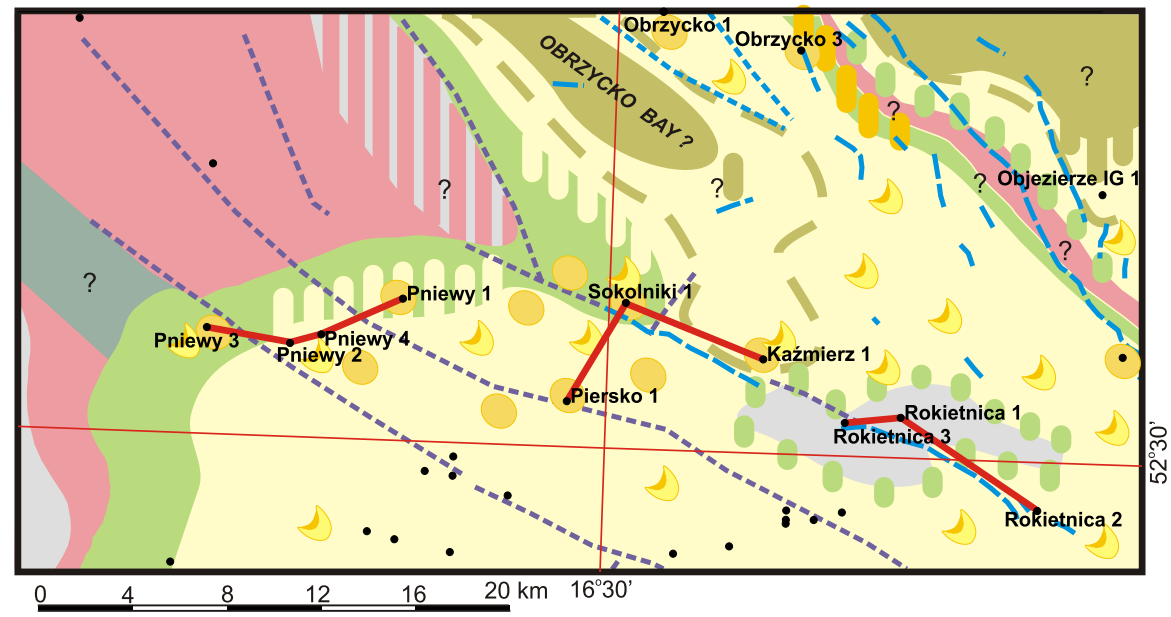

Fig. 22. Palaeogeographic-facies map of the study area (depositional unit 5)

For explanations see Figure 18

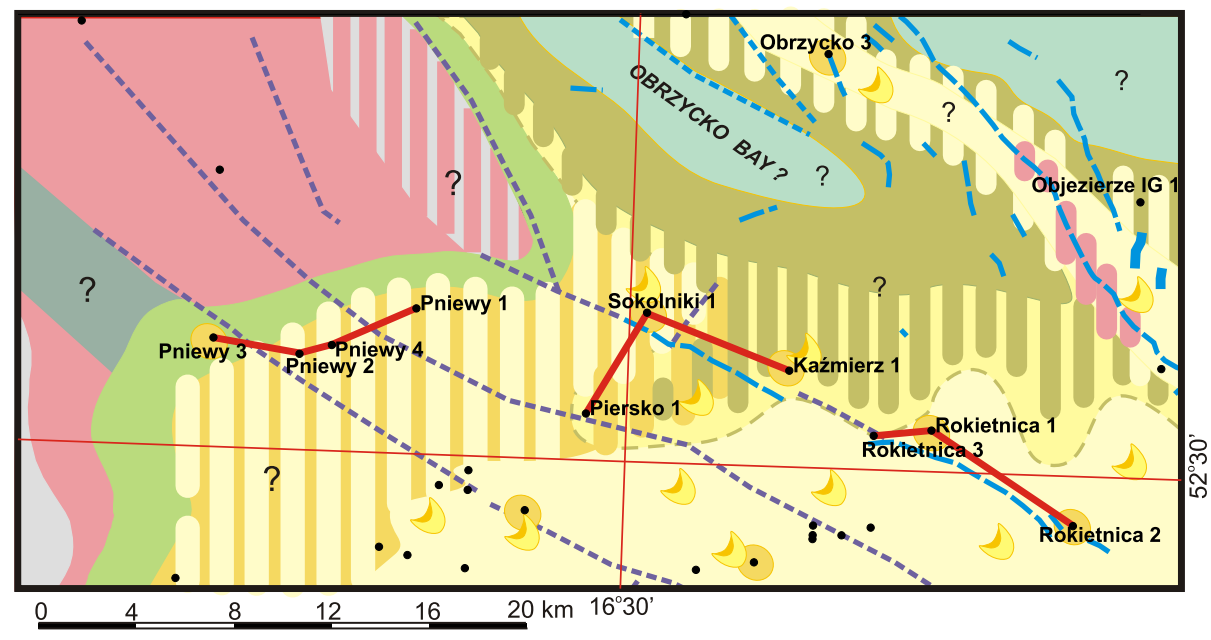

Fig. 23. Palaeogeographic-facies map of the study area (depositional unit 6)

For explanations see Figure 18

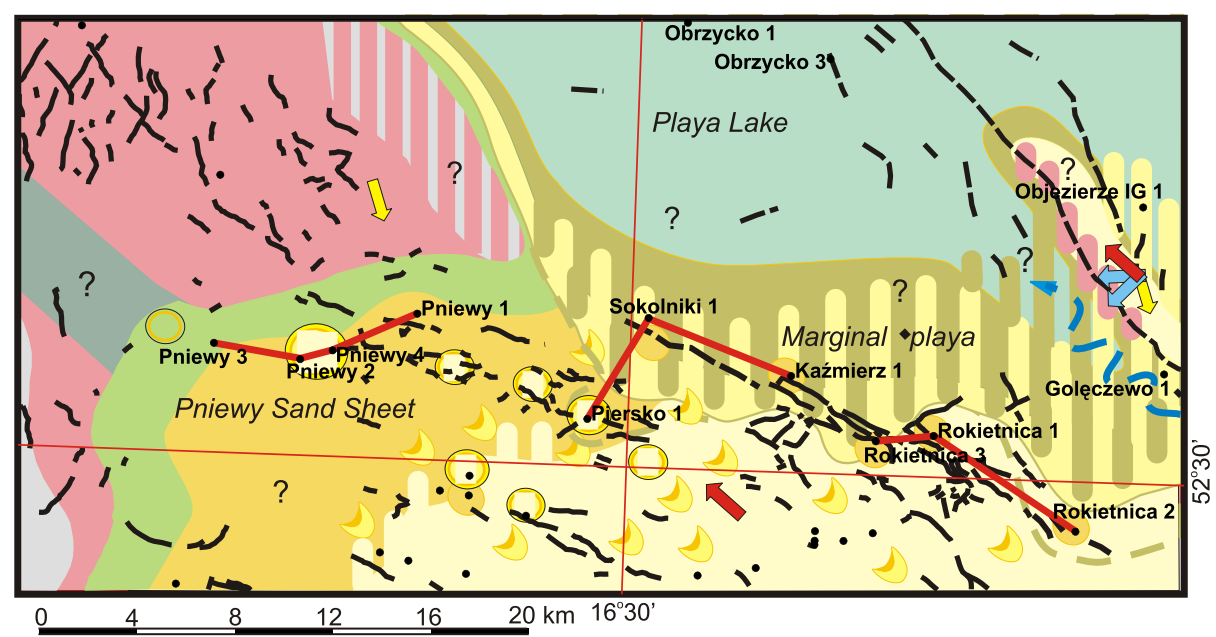

Fig. 24. Palaeogeographic-facies map of the study area (depositional units 7-9)

For explanations see Figure 18
In the Rotliegend section of the Obrzycko 3 borehole (Fig. 3), we can see a rapid transition from aeolian sedimentary conditions (dunes and sand sheets) to marginal playa conditions. This rapid change in sedimentary conditions proves an episode of sudden wetting and resulting expansion of the playa-lake. This boundary shows features of a sequence boundary (SB). Above, in the section, there is a MWS-type bounding surface (Maximum Wetting Surface). The marginal playa deposits are nearly $40 \mathrm{~m}$ thick and are represented by a fining-upward cycle.

The alluvial deposits have a thickness of up to $9 \mathrm{~m}$. They consist of a number of channelized and non-channelized sheet floods, as well as thin interbeds of sand sheets.

This complex is terminated by a selected erosional boundary, in some boreholes related to the Zechstein Sea transgression.

Depositional Unit 9. The ninth, youngest depositional complex, consists of aeolian sandstones of dunes They are preserved only locally, have a thickness from 20 to $30 \mathrm{~m}$, and represent a remnant of the original, vast aeolian sedimentary cover that was subjected to erosion. Its fragments have been preserved, owing to their immediate covering by Zechstein Sea deposits (Fig. 24).

Stacked complexes of aeolian deposits, separated by erosional boundaries, including subhorizontal, have been distinguished in the preserved fragments of the aeolian sedimentary cover in the Pniewy 2, Pniewy 4 and Piersko 1 boreholes (Figs. 16 and 17). In some parts of the section, the boundaries are densely distributed. This is also associated with strong rotations of dip azimuths of lamina sets (from 50 to $150^{\circ}$ ), as measured in the core sections (Fig. 13).

In many places, erosion of the dune complex reached the top of sand-gravel sheets that are the basement of the aeolian complex (depositional units 7 and 8), and were more resistant to weathering, due to both early cementation and the occurrence of groundwater at their top. Strong erosion resulted from the lowering of erosional base levels and the consequent lowering of groundwater levels. The groundwater level lowering might have been caused by longstanding hydrogeological drought, fluctuations of the playa-lake level, or 
by partial or total tectonic uplift of the western part of the Poznan Basin. A similar example of uplift and erosion of the Rotliegend aeolian deposits is known from the Upper Rotliegend Silesian Basin (Pakosław-Janowo area; Kiersnowski and Tomaszczyk, 2010).

Erosional processes of ergs also occurred earlier, leading to the formation of smooth erosional surfaces (super-surfaces) (Loope, 1985). In this case, the process of sub-aerial erosion was interrupted by the Zechstein transgression.

If the transgression would have advanced upon a dune field, then the deposits, formed due to erosion of the dune, would consist of the same sandstones as those composing the dune. In the case of the eroded dunes from the Pniewy 4 borehole, the erosional boundary of the dune, composed of fine- and medium-grained sandstones, is capped by sandstones with admixture of coarse sand and fine granule-size grains (Fig. 13).

Above the transgressive deposits, no Kupferschiefer is found but, there is thin Zechstein Limestone (Ca1) (condensed sequences - Peryt and Ważny, 1980; Peryt et al., 2015). It proves that eroded land was a significant geomorphic feature, which represents a remnant of the original sedimentary cover, composed of aeolian deposits and minor alluvial sediments. In the case of the top of aeolian deposits from the Pniewy 2 borehole, the eroded structure was higher and the aeolian sandstones are immediately overlain by the Ca1 (Fig. 16). The aeolian complex shows features of stratigraphic condensation, and the numerous interbeds of sand sheets, partly laminated with coarse-grained sandstone, making it similar to those from the Sokolniki and Kaźmierz sections. A coarsening-upward trend is observed in the section.

\section{DEPOSITIONAL CYCLES, PALAEOCLIMATIC CYCLES AND THE PHENOMENON OF SAND SHEETS}

In the western part of the Poznan Basin we encounter, almost exclusively, a complex of basin-margin deposits: alluvial, aeolian and marginal playa sediments (Figs. 18-28). They are characterized by a considerable number of erosional gaps. Thus, the interpretation of climatic cycles is possible based only on depositional complexes that provide evidence for climate fluctuations in the sedimentary record.

Climatically controlled depositional complexes and cycles are described from the Upper Rotliegend of the Dutch-UK part of the Rotliegend Basin (George and Berry, 1997; Howell and Mountney, 1997; Van Ojik et al., 2011). Minervini et al. (2011) provide a good reference in their analysis of the depositionally variable Upper Rotliegend deposits in the Sole Pit Basin, located in the western part of the Southern Permian Basin. These are alternating aeolian (including erg margin), alluvial, fluvial (and lacustrine), floodplain, playa and playa-lake deposits. Five major depositional units have been distinguished in that region, which include 16 lower-order depositional units (Fig. 25).

Deposits in the Polish Upper Rotliegend sedimentary basin were divided into six sedimentary sequences by Karnkowski (1999). These sequences encompass whole Upper Rotliegend deposits. Whereas, the Dutch-UK part of the Rotliegend Basin, compared with the Poznań Basin, represents only the upper part of the Upper Rotliegend strata. Sedimentary sequences in Karnkowski (1999) are not clearly defined and are interpreted as caused by either climate or tectonics or both. Therefore, they are not summarized in Figure 25.

In the analysed depositional succession, boundaries of the depositional units, considered to have been controlled by climatic change, are in place in some sections at the base of fluvial or al- luvial complexes, which are separated from aeolian deposits by an erosional boundary. It corresponds to the wet-dry-wet cycles observed in Rotliegend deposits of the western part of the Southern Permian Basin (George and Berry, 1997; Howell and Mountney, 1997). However, it should be borne in mind that such sequences are tied to the lithostratigraphy of the great salt lake that existed in the central part of the Southern Permian Basin (Gast, 1991; Legler, 2006). Alternating claystones, mudstones and salts form a set of cycles reflecting climate fluctuations in that region (Yang and Nio, 1993; Legler and Schneider, 2013). In their middle part, the deposits show no erosional gaps and represent a complete sedimentary record. This is optimal for the analysis of climatically controlled cyclicity. The boundaries referred to as the Major Bounding Surface (MBS), Sequence Boundary (SB) and Maximum Wetting Surface (MWS) have been extended into poorly separable alluvial, fluvial and aeolian deposits from the marginal part of the Rotliegend Basin (Van Ojik et al., 2012).

The analysed sedimentological sections contain structures proving wetter episodes. These are: bioturbation horizons and presumed root traces (Figs. 5 and 11); intermittent pond deposits (Fig. 7); scour horizons in sediments, characterised by homogeneous depositional conditions such as sand sheets (Fig. 9); and scour structures on dune field surfaces (Fig. 11). Some of these horizons occur only in a single section, while others seem to continue into nearby sections (Figs. 16 and 17). In this situation, these horizons would be related to a higher-rank process identified here with a regional event having been an analogue to the MWS. This is recognized in the Dutch-UK part of the Rotliegend Basin (Van Ojik et al., 2011). It is also probable that only some of the identified horizons are really of basinal rank and may be linked with playa extent fluctuations in the central part of the Polish Rotliegend Basin. Some of them may be of local occurrence and are likely associated with pedogenic horizons; described in the Upper Rotliegend section of the Sława IG 1 borehole drilled in the Silesian Basin (Kiersnowski, 2015; Fig. 25).

Some of the boundaries, between the depositional sequences, are placed at the base of sand and sand-gravel sheets; assuming that the transition from dune or mixed, dune-alluvial deposits, to well-developed sand sheet deposits is associated with a significant and permanent change of sedimentary conditions.

\section{SAND SHEETS}

Sand sheets have been defined by Fryberger et al. (2011) as "...lenticular bodies of mostly flat or low-angle aeolian ripple strata, commonly with minor amounts of other types of strata, including, in places, fluvial and pond deposits (Fryberger et al., 1979). Sand sheets may also include lower portions of migrating dunes, dome dunes, blowouts, and zibar and granule-ripple deposits".

Sand sheets have been described from the Rotliegend of the Dutch-British part of the Rotliegend Basin (George and Berry, 1997; Fryberger et al., 2011). George and Berry (1997) classified them as interdune facies (interdune - A4 dry interdune - interdune sheet). They are not designated as a separate category of the extradune sand sheet type.

Two sequences of horizontal and sub-horizontal sand sheets, 5-9 m thick, were described from the Yellow Sands exposures in the British, western part of the Southern Permian Basin (Clemmensen, 1989). They underlie a system of linear compound dunes and occur at the top of the compound dunes (Steele, 1983; Chrintz and Clemmensen, 1993), which represent the uppermost sequence of the Rotliegend deposits overlain by the Zechstein Marl Slate. 


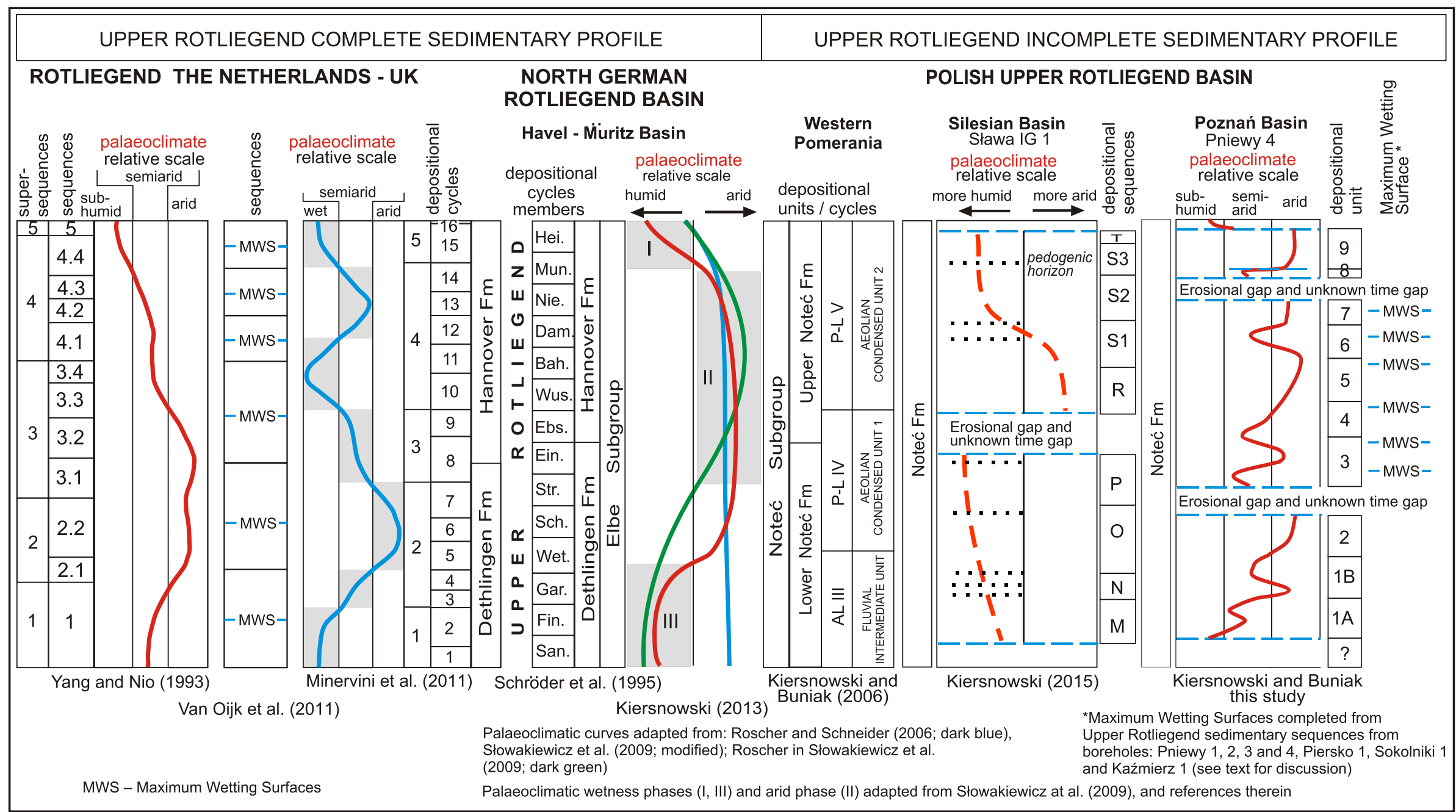

Fig. 25. Aeolian dune - sand sheet depositional system of the western margin of Poznań Basin (Noteć Fm.) 
In western England, an $8 \mathrm{~m}$ thick Permian low-angle sand sheet was described. It contains lenticular to tabular strata of well-laminated and ripple cross-laminated sandstones (Karpeta, 1990). The sandstones are bimodal, with layers of coarse granule lags. Curved internal erosion surfaces were identified, which also occur in the sand sheet sections discussed in the present paper (Fig. 9; Pniewy 2, 3511-3537 m).

In the Permian Arran Basin in Scotland, plane-bed laminated sandstones were described (Clemmensen and Abrahamsen, 1983). These are frequently accompanied by more coarse-grained aeolian facies, such as granule ripples or granule-reach horizons. The sequence reveals bimodal lamination and a coarsening-upward trend. Scattered grains were reported, 7-9 $\mathrm{mm}$ in size. As an explanation for this type of sedimentation, Clemmensen and Abrahamsen (1983) suggested high wind velocities and a relationship with nearby fluvial deposits containing gravel fractions.

Sand and sand-gravel sheets are widespread in the Upper Rotliegend of the western part of the Poznan Basin, where they have a considerable thickness and are often "independent" of dune deposits, in fact replacing them. Sand sheets that occur as classic interdune deposits are in minority. They are more frequently observed as interbeds in dune complexes of greater thickness. In the study area, sand sheets are dominant. They have been classified as extradune sand sheets. That is why they show frequent interactions with fluvial and alluvial deposits occurring in the marginal part of the basin. Sand and sand-gravel sheets also form numerous interbeds in alluvial sediments. Their thickness and frequency of occurrence, in the analysed sections, suggest that they are grouped within three main depositional cycles (Fig. 16).

Sand sheets occur separately over an extensive area and have a thickness of a few metres or, they form thicker stacked sand sheets. Thick stacked sand sheets develop as a result of long-lasting stabilization and equilibrium, which occurs between the processes of accretion and erosion, in connection with the scarcity of sources of aeolian material.

Detailed analysis of dips of laminae, in the individual sand sheet sets, shows that this is not only horizontal or sub-horizontal sedimentation, but also shows there are low-angle inclined lamina sets and low-angle plane bed lamination, probably representing large-scale forms with lenticular geometry.

Conditions favouring the formation of sand sheets. Sand sheets develop under favouring geomorphic and climatic conditions. Their development and thickness depend on the stability of the factors which control their deposition.

The key condition is aeolian transport on a relatively flat land surface. Sand sheet deposits accumulate on the surface of alluvial deposits, and on the erosional surface of dune fields. Horizontal or low-angle erosional surfaces, under conditions of arid or semi-arid climate, are an effect of morphogenic activity of the wind. This activity is dependent on wind velocity, moisture of the bedrock, and its lithology. Bedrock moisture depends on the occurrence of groundwater, imbibition, and the stability of capillary water over a long period of time (Kocurek and Nielson, 1986). In desert areas, the deflation process that reaches down to groundwater level may result in the formation of flat surfaces; such as vast, long, low-angle depressions.

Regional erosional surfaces may be ranked as: first-order erg surface (Brookfield, 1977), super surface (Kocurek, 1988), or sand-drift surface (Clemmensen, 1990). Such surfaces may be extensive and traceable for long distances. Frequent winds caused drying of the depositional surface, and enabled remobilization of the deposited sediment. This gave rise to the formation of extensive sequences consisting mainly of wind ripple strata (Maxwell and Haynes, 2001), structureless sand plinths
(Brookes, 2003), and to the development of migrating small dunes of barchans type. Under special circumstances, vast low-angle aeolian forms (lacking slip face), like dome dune or zibar, can form on extensive areas (Maxwell and Haynes, 2001; Fig. 29).

The term "plinth" is used in this paper for the description of vast, semi-planar structureless, or stratified aeolian forms. It also refers to the sloping margin of a linear dune, comprised mainly of aeolian ripple strata, as observed by S. Fryberger (written comm., 2016).

The grains in the sand sheet are represented by those that originate from saltation, and those deposited from suspension. These are shaped and transported as wind ripples (Sharp, 1963). Sand sheets consist of hundreds and thousands of laminae that are shaped in the process of the migration of wind ripples (cf. Fryberger et al., 2011). In the case of flat, levelled surfaces, the individual laminae cannot be thicker than the wind ripples that formed them. In general, the laminae are not thicker than $5 \mathrm{~mm}$. The total thickness of sand sheets was dependent on the stability of the main factors determining their development; such as wind and capillary imbibition. The thickness was also dependent on the stability (balance) of the accommodation space (Kocurek and Havholm, 1993), and the lack of, or scarcity of, sand sources for dune deposits to be formed.

Sand sheets, analysed and described in the literature, contain interbeds of basal elements of dunes. This indicates periodic changes in depositional conditions. The formation of migrating, or fixed aeolian forms could durably, or temporarily disturb the development of sand sheets. However, the observed erosion of the aeolian forms indicates levelling equilibrium of the sand sheet surface. The persistence and aggradation of low-angle aeolian sand sheet deposits, and their distinct separation with the participation of coarse-grained sandstones, may be the effect of a bimodal local wind regime (Fryberger et al., 1979).

Sand and sand-gravel sheets are composed of flat, parallel lamina sets that lie horizontally, or at a small angle (up to $5^{\circ}$ ). There are also thicker sets of laminae inclined at an angle of ca. $8-10^{\circ}$. According to Fryberger et al. (2011), a slight dip may indicate a tectonic structure or the proximity to the dune apron. According to McKee (1966), horizontal or low-angle, tabular, planar lamination, that begins with a flat eroded base, occurs commonly in dome-shaped, transverse, barchanoid and parabolic dunes (Fig. 29).

In an environment where large dunes could be formed, their lower elements are preserved. This is characterized by a gradual increase in lamina dips. In very large aeolian forms, these lower elements can attain considerable thickness and imitate an inclined sand sheet, e.g. giant ripple marks and forms that are 1,500 $\mathrm{m}$ across and $0.5-1.0 \mathrm{~m}$ high; which occur on the modern Selima sand sheet (Breed et al., 1987; Maxwell and Haynes, 1989). In addition, the development of sand sheets can be associated with the formation of extensive, low-angle aeolian forms of dome dune type (with no or poorly developed slip face) or, if the sandstones are coarser-grained, these forms are referred to as zibar (Biswas, 2005; Biswas et al., 2014). Such forms, if preserved in the sedimentary record and examined in drill cores, are practically indiscriminable from "classic" sand sheets.

The aeolian forms described as "zibar" are common in sand sheet areas. These zibar dunes (Simplicio and Basilici, 2015), are probably separate from "classic" sand sheets; assuming both the sand sheet lamination sedimentary deep is between 0 (horizontal) $-5^{\circ}$, and the zibar (sloping sand sheet) lamination sedimentary deep is between $5-10^{\circ}$. The limit of $10^{\circ}$ should be analysed in terms of conditions that are favourable for forming lee slope on dune forms (Fig. 29). 


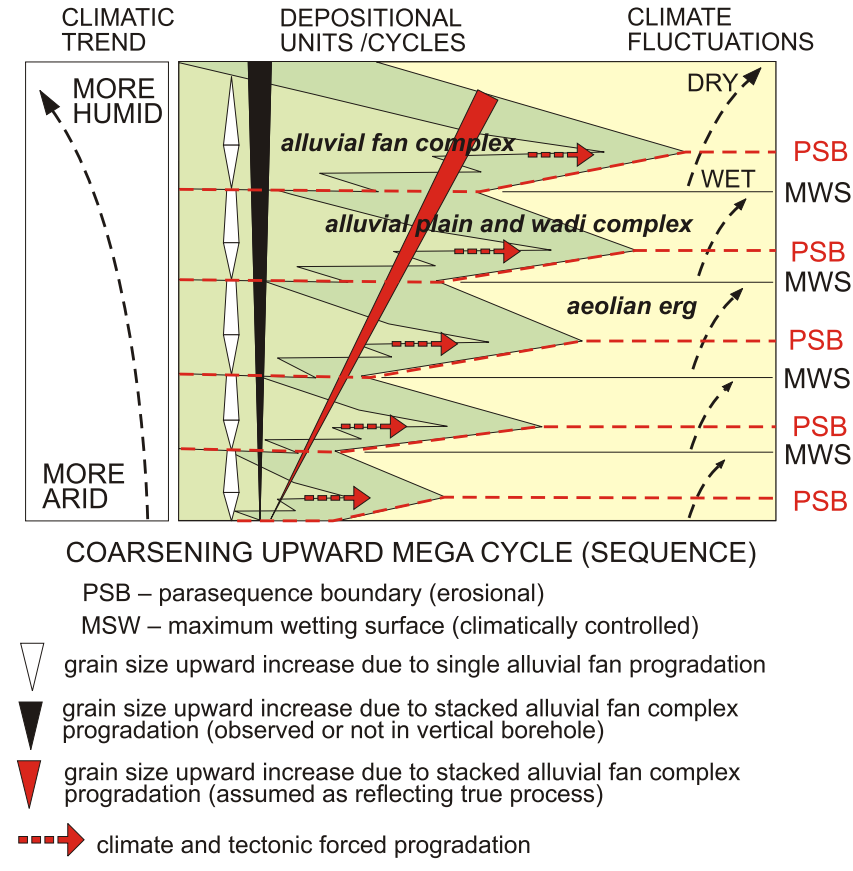

Fig. 26. Basin margin alluvial depositional system versus aeolian depositional system; model is related to the western margin of the Poznań Basin

The authors assumed that zibars can represent a slowly migrated sand sheet cover. This contradicts the idea that low angle cross bedding $\left(<10^{\circ}\right)$ represents undeveloped proto-dunes or the truncated base of large dunes. Zibars have consistent low angle lamination when dune base units show a gradual upward-increase in lamina dip angle. The units with gradual upward-increase in lamina dip angle may represent remnants of "trailing" facies of a migrating sand sea, as suggested by S. Fryberger (written comm., 2016). The phenomenon of stacked zibars, sand sheet complexes that formed an unusually thick sedimentary succession (Simplicio and Basilici, 2015), proves significant and suggests a secreted aeolian bedform.

Cross-laminated aeolian interbeds have been recorded and interpreted as being parts of lower elements of migrating dunes with a preserved slip face (Figs. 5 and 7). Sand and sand-gravel sheets are common in the borehole sections. They form regional correlation horizons. The correlations were applied in the analysis of the Rotliegend deposits from the Pniewy 1, 2, 3 and 4, as well as Piersko 1, Sokolniki 1 and Kaźmierz 1 boreholes (Figs. 16 and 17). In the area of Pniewy boreholes, three depositional cycles are distinguishable (Fig. 16). They are characterized by an increase in both the frequency of occurrence of sand sheets, and the proportion of sand-gravel sheets. At the top of these cycles, sand and sand-gravel sheet deposits definitely prevail over dune and alluvial deposits (Fig. 28).

Table 1 provides a summary of the sand sheets with respect to their proportions in the sedimentological sections (of similar thickness). These are relative to the proportions of alluvial and aeolian (dune) deposits. The maximum thickness of sand sheets is also given; with the restriction that the sheets represent stacked sand sheets, and their total thickness can result (in some cases) from the lack of clear erosional boundaries separating the individual episodes of their deposition.

The sand sheets in incomplete drill cores, from the Piersko, Sokolniki and Kaźmierz boreholes (Table 2), are better developed and preserved toward the south - the erg interior.

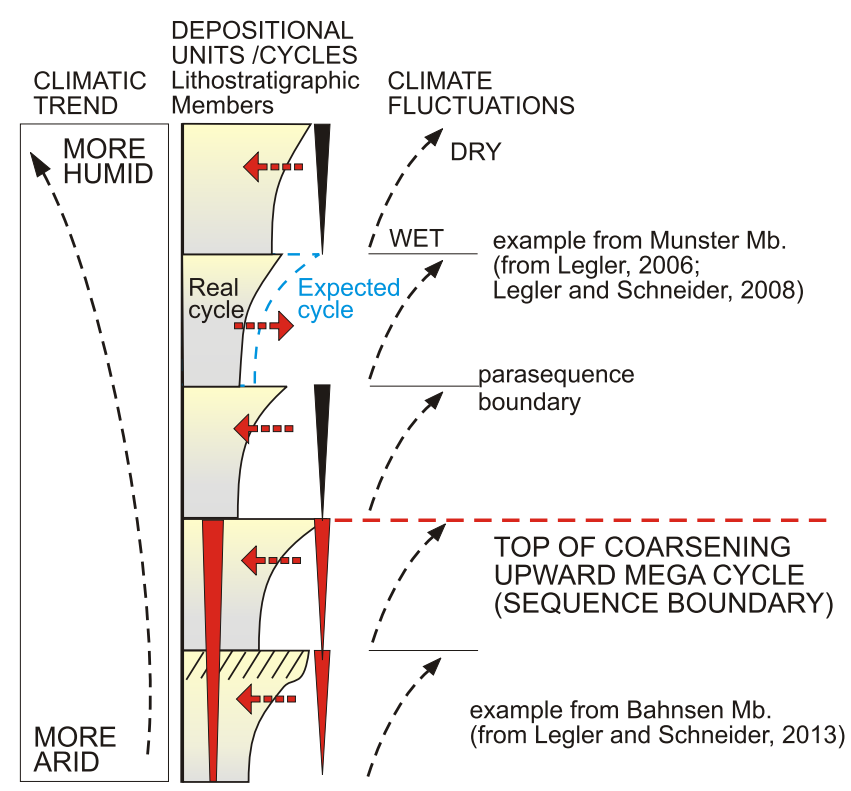

weak grain size upward increase (observed in vertical borehole)

7 considerable grain size upward increase (observed in vertical borehole)

climate forced lateral shift of facies belts towards basin centre climate forced lateral shift of facies belts towards basin margin

Fig. 27. Saline lake - mud flat - sand flat depositional system of the North German Basin (Upper Hannover Fm.)

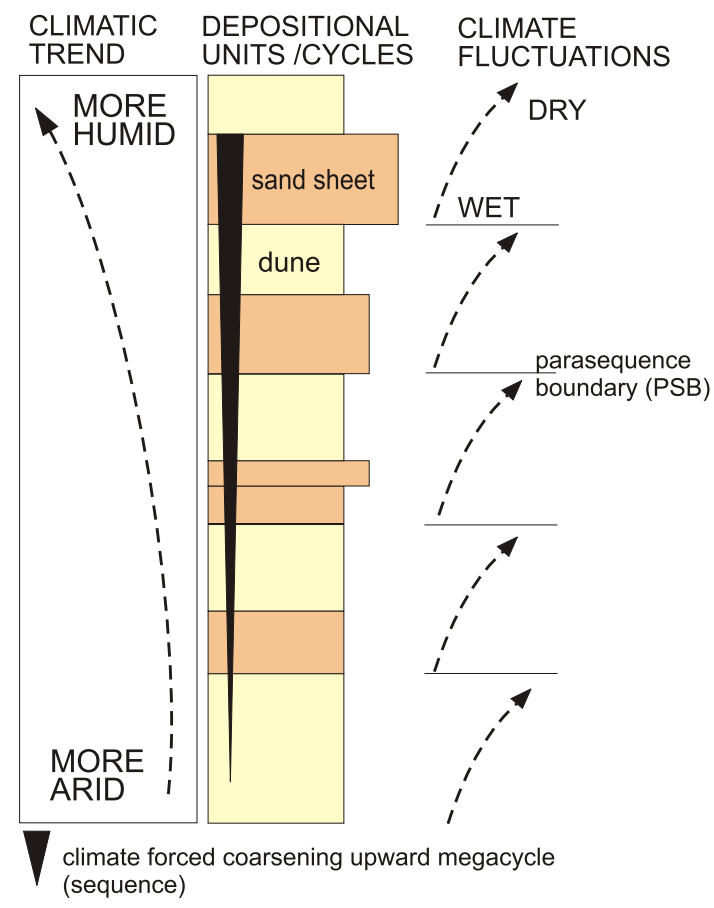

Fig. 28. Depositional units (parasequences) versus palaeoclimate cyclicity inferred for stacked sequence of interbedding dunes and sand sheets Pniewy sand sheet area

The presence of granules, scattered or as granule-rich lags, has been recorded in the sand and sand-gravel sheets. Granules, that are close to coarse sand grains in size, were determined in the sedimentological record as V.C. - very coarse. 
LOW ANGLE STRATIFIED AEOLIAN BEDFORMS

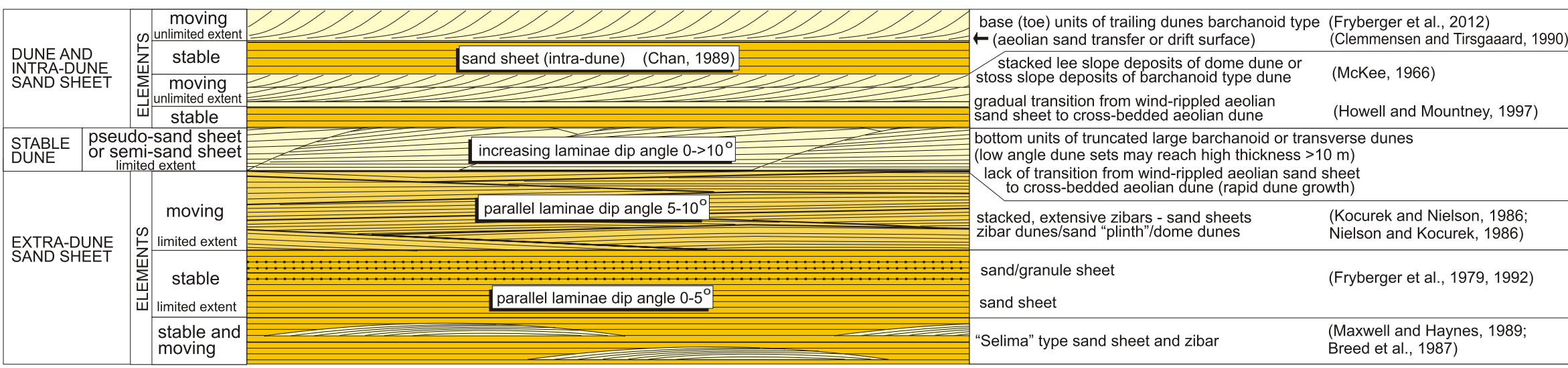

W

SIMPLIFIED DEPOSITIONAL ARCHITECTURE OF STUDY AREA

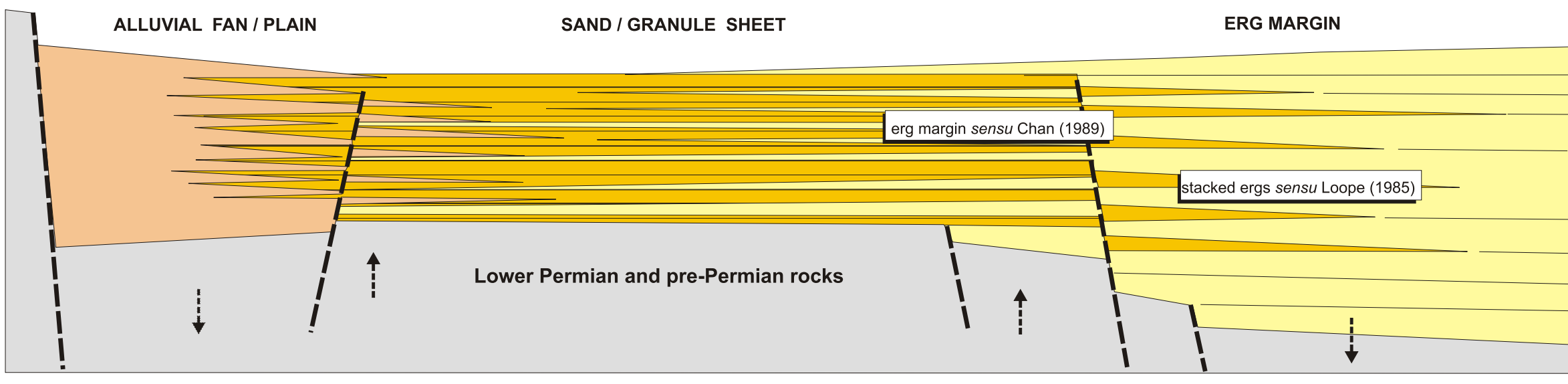

Moderate accumulation rates

Low accumulation potential

High accumulation rates

Fig. 29. Low angle stratified aeolian bedforms and depositional architecture of study area 
Sand sheets in the Pniewy area - a summary

\begin{tabular}{|l|c|c|c|c|}
\hline Borehole & $\begin{array}{c}\text { Thickness of sand sheets (ss) (including } \\
\text { VC) for interval from conventional top } \\
\text { of ss to 50 m depth }\end{array}$ & $\begin{array}{c}\text { Thickness of sand sheets (ss) (including } \\
\text { VC) for interval from conventional top of } \\
\text { ss to 80 m depth }\end{array}$ & $\begin{array}{c}\text { Maximum } \\
\text { thickness of } \\
\text { sand sheets }\end{array}$ & Lower part of section \\
\hline Pniewy 3 & $16(12.5) \mathrm{m}$ & $\begin{array}{c}26.5(17.5) \mathrm{m} \\
\text { for } 85 \mathrm{~m} \text { of deposits }\end{array}$ & $>3.5 \mathrm{~m}$ & $\begin{array}{c}15(>1) \mathrm{m} \\
\text { for } 34 \mathrm{~m} \text { of deposits }\end{array}$ \\
\hline Pniewy 2 & $21.5(8) \mathrm{m}$ & $29(11) \mathrm{m}$ & $6.5 \mathrm{~m}$ & \\
\hline Pniewy 4 & $14.5(6) \mathrm{m}$ & $19.5(8) \mathrm{m}$ & $6 \mathrm{~m}$ & \\
\hline Pniewy 1 & $>21(>12) \mathrm{m}$ & $>34.5(>12) \mathrm{m}$ & $>8.5 \mathrm{~m}$ & \\
\hline
\end{tabular}

Table 2

Sand sheets in Piersko, Sokolniki and Kaźmierz area - a summary

\begin{tabular}{|c|c|c|c|c|}
\hline Borehole & $\begin{array}{c}\text { Summarized } \\
\text { drill core [m] }\end{array}$ & $\begin{array}{c}\text { Summarized } \\
\text { gaps in cored } \\
\text { interval [m] }\end{array}$ & $\begin{array}{c}\text { Sand sheet thickness } \\
\text { and percent of measured } \\
\text { borehole }\end{array}$ & $\begin{array}{c}\text { VC } \\
\text { only }\end{array}$ \\
\hline Piersko 1 & 43 & 3.5 & $>31.5 \mathrm{~m}(73.2 \%)$ & $4 \mathrm{~m}$ \\
\hline Sokolniki 1 & 62 & $>12.5$ & $19.5 \mathrm{~m}(31.5 \%)$ & $<2 \mathrm{~m}$ \\
\hline Kaźmierz 1 & 70.5 & 10.5 & $20 \mathrm{~m}(28.4 \%)$ & ca. $2 \mathrm{~m}$ \\
\hline
\end{tabular}

The granules are sub-rounded and are $4 \mathrm{~mm}$ across (some even $4.5 \mathrm{~mm}$ ). Similar grain size was reported in the literature concerning the formation of coarse-grained sand sheets (Fryberger et al., 1979, 1992).

The increase in wind strength enabled the distribution of fine gravel grains; those blown away from the source areas. These grains are represented predominantly by clasts of volcanic rocks, and by rounded and sub-rounded quartz grains. The wind strength, near ground surface, determined the size and weight of the grains transported in suspension. This occurred either by saltation, or by surface creep. An intermediate process, between saltation and surface creep, has also been described. This process, referred to as repetition, describes creeping, larger (granule) grains that are pushed by finer saltating grains. The capturing and holding of the grains in the ground was controlled by the substrate moisture. Substrate moisture was dependent on multi-frequency periods of capillary imbibition. Capillary imbibition on a large area could indicate a relatively levelled palaeorelief, devoid of permanently wet or constantly dry terrains.

Geomorphological significance of sand sheets in relation to dune and alluvial deposits. In the Piersko-Sokolniki-Kaźmierz area, the deposits are highly stratigraphically condensed and separated by numerous erosional boundaries (Fig. 17). Three depositional cycles appear by means of an increase in the frequency of occurrence of sand sheets, and by an increase in the proportion of sand-gravel (granule) sheets.

The presence of portions of dunes separating alluvial deposits may support the interpretation that the alluvial periods, determined as humid, were in fact semi-arid periods with intervals of flash floods due to heavy rainfall. Similarly, flash floods, from torrential rains, might have caused strong erosion of sand sheets. It can be assumed that, in areas where sand sheets or dune deposits are interbedded with alluvial deposits, alluvial fans developed under a climate favouring aeolian processes. However, the probable progressing trend of climate wetting might have caused increasing dominance of the alluvial depositional system.

Fast aeolian aggradation of alluvial cover deposits, observed in the borehole sections, could affect the extent of the development of alluvial fans, masking their potential distribution. Thus, the development of alluvial fan deposits was controlled by uplifting and subsidence along the tectonic margin, and by the migra- tion of aeolian dune fields, in a direction opposite to the progradation of alluvial fan deposits (Kiersnowski, 2013; Figs. 26 and 29).

The sheet flood deposits locally pass into initial sand sheets. It is not clear whether this is a gradual change of sedimentary environment, or an effect of interbedding of distal sheet floods with a developed system of sand sheets. Abrupt or gradual changes in sedimentary environments reflect palaeoclimate fluctuations.

According to Howell and Mountney (1997), the development of sand sheets was favoured by climate wetting in association with a groundwater level rise. An example of such a wetting process is provided by the observed frequent interbeds of alluvial and sand sheet deposits, as well as intraformational scours (e.g., Fig. 8). In turn, an arid change in climate caused a migration of dunes across or within the sand sheets.

In conclusion, the sand sheets are well-developed in the flat area (transition zone), located between the alluvial dominated territory (groundwater source), and the aeolian dune dominated territory (sand source). The extent of the sand sheet area is determined by the equilibrium of the accommodation space (Fig. 29).

Semi-sealing properties of sand sheets. Damp and wet interdune and extradune deposits - clay-mud sheets deposited in periodic small ponds, and sand and sand-gravel sheets - can represent intraformational barriers or seals to hydrocarbon migration within depositional complexes. This is due to the low permeability of mudstone and claystone interbeds. They are also caused by the presence of clay-ferruginous matrix and cementation, by anhydrite and carbonate, in thick sets of sand and sand-gravel sheets (Muszyński, 1999). In the Pniewy region, the measured vertical permeability values are very low, ranging from 0.001 to $0.060 \mathrm{mD}$. The lateral permeability values are higher and attain $1 \mathrm{mD}$. On the other hand, Poszytek (2014) reported moderate reservoir properties of sand sheet facies, ranging between $0.1-10 \mathrm{mD}$ of horizontal permeability and $2-19 \%$ of helium porosity, from the Zielona Góra-Silesian Basin (Upper Rotliegend Southern Erg).

Extra-dune sand sheets can be more widespread in lateral extent than interdune sand sheets. Thus, they can provide a better regional sealing effect. The significance of sand sheets, as possible sealing horizons in the western part of the Southern Permian Basin in the Dutch sector, was highlighted by Fryberger et al. (2011). In the British sector of the North Sea, numerous interbeds of sand sheets were also described as having very poor to non-existent reservoir quality (Leveille et al., 1997).

Rotliegend deposits of the Pniewy 1 and Pniewy 3 boreholes contain intraformational seals (thick sand sheets), that are tight enough to trap gas in more permeable layers (referring to POGC gas content logs). These seals are associated with sand sheets and layers of fine-clastic sediments. These are interpreted as representing intermittent ponds. 


\section{PALAEOCLIMATIC CONSEQUENCES}

The Rotliegend deposits in the areas of the Sokolniki-Rokietnica tectonic high, and the highs of the GolęczewoObrzycko tectonic zone have the following thicknesses: Rokietnica 1 ca. 70 m, Rokietnica 3 ca. 80 m, Rokietnica 2 ca. 120 m, Obrzycko 3 ca. $100 \mathrm{~m}$. These thicknesses are similar to those observed in the boreholes: Sokolniki 1 ca. 75 m, Kaźmierz 1 ca. $75 \mathrm{~m}$, Pniewy $1 \mathrm{ca} .80 \mathrm{~m}$ and Pniewy $4 \mathrm{ca} .125 \mathrm{~m}$. Despite these similar thicknesses, the sections differ slightly in terms of sedimentary environments.

The sections of boreholes drilled near the border zone of the basin show a considerable proportion of alluvial deposits, relative to aeolian deposits of dunes and sand sheets (Fig. 16). Borehole sections which are most distant from the border of the sedimentary basin are dominated by aeolian deposits: dune and minor sand sheets, with no clear participation of alluvial deposits.

The observed trend of lateral facies changes, relative to the distance from the source area, is accompanied by an increase in the size of grains transported by wind-driven saltation, especially in the top portions of the Rotliegend. This is marked by both a gradual, or rapid increase in sandstone grain size in dune deposits, and the occurrence of granules in sand and sand-gravel sheets, which are scattered or occurring as granule-rich lags. Their threshold diameter is $4 \mathrm{~mm}$. This is typical of very fine gravel referred to as granule. The grain size was limited by two factors: both wind speed and distance from the source area, and by the type of material prepared for aeolian transport. This is significant for palaeogeographic and palaeoclimatic analyses because larger grains require both a suitable substrate, and the wind speed necessary for long-distance migration. Grains larger than one millimetre across are not transported by saltation, and are generally moved by another process called surface creep (Sharp, 1963).

In the analysed sand and sand-gravel sheets, the grains mostly represent weathering from the exposed Lower Permian volcanic rocks (K. Chłódek, pers. comm., 2015). The uniform diameter of transported grains is, in part, the resulting grain sizes favoured by various wind velocity thresholds. It is also an outcome of typical size ranges, devolved from the gradual disintegration of volcanic source rocks for Rotliegend sand.

\section{CAUSES OF THE COARSENING-UPWARD TREND} IN THE UPPER ROTLIEGEND

The causes of the coarsening-upward trend depend on the climatic and tectonic controls. In the case of alluvial deposits, this can be related to a stacked alluvial prograding complex giving a coarsening-upward megacycle (Fig. 26). Alluvial fan deposits were developed along an active tectonic scarp, which gradually increased the accommodation space on the down-dropped side. Each significant wet cycle triggered progradation of alluvial fans. In our study area, migration direction of aeolian dunes, during dry periods, was opposite to the direction of alluvial fan progradation. Accumulation of aeolian sands resulted in a rise of the erosional baseline for the next alluvial fan; preserving aeolian sediments beneath.

Within the Erg, such an erosional boundary is a parasequence boundary (PSB) (Fig. 26). This corresponds to the identification of sequences in the alluvial deposits of the Dutch part of the Rotliegend Basin (Van Ojik et al., 2011); although there are no correlations between the Polish part of the basin and the siliciclastic-evaporitic German-Dutch Basin. In the case of the Pniewy Zone, the coarsening-upward megacycle (grains/clasts) can be an effect of an allochthonous factor, i.e. increasing climate humidity.

A coarsening-upward trend in the top parts of the Upper Rotliegend is observed at the top of fine clastics of the Hannover Formation in the North German Basin (Legler and Schneider, 2008). B. Legler writes: "In the upper part of the Hannover Fm, we see an additional coarsening-upwards trend from Munster to Heidberg Member; with the highest amount of mudstones related to lacustrine deposits in the Munster Member (widest lake expansion due to the repeated marine ingressions). In the Heidberg Member, we have not observed/interpreted marine ingressions, and the Heidberg Member is overall sandier than the underlying Munster Member." This observation is illustrated in Figure 27.

Referring to their Figure 4A, Legler and Schneider (2013) argue that sedimentary cycles of different time scale are imprinted in the sedimentary record. For example, from the Bahnsen $\mathrm{Mb}$, borehole Rhinow 5, a tens of metres thick, drying-wetting upward cycle is interpreted to represent ca. $400 \mathrm{ka}$, composed of several ca. 100 ka and ca. 20 ka cycles (Gast, 1993, 1995).

However, termination of the coarsening-upward megacycle occurred at the end of deposition of the Dambeck Mb. (Hannover Formation; Legler, 2006; Fig. 27). This is related to the processes of both climate drying increase, and the migration of the aeolian lithofacies belt towards the central part of the North German Basin.

A similar situation is observed in the Upper Rotliegend section of the Września IG 1 borehole, located in the eastern part of the Eastern Erg (Fig. 1). Studies performed by the senior author show that the fine-grained aeolian sandstones display a clear increase in the proportion of coarse sandstone laminae. However, considering the grain-size increase within the megacycle of the Pniewy region (Fig. 28), this process was instead associated with a trend of gradual increase in humidity. It seems that depositional units 7 and 8 can reflect a palaeoclimatic record of gradual climate change from arid to semi-arid, as interpreted in the German and Dutch-British parts of the Rotliegend Basin (Fig. 25).

The increasing grain-size trend is interpreted as being the result of progressive drying (which enables aeolian transport), in connection with increasing wind velocity and constancy (stronger and more persistent winds). The map (Fig. 24) shows averaged directions of aeolian transport, resulting from the analysis of dips and azimuths of strata in aeolian deposits of the Eastern Erg (Kiersnowski, 2013).

The size of arrows reflects the importance of the individual directions of aeolian transport. This shows that clasts of volcanic rocks could be transported from the Gnuszyn High area by periodic northwesterly winds. Further, it shows that clasts of volcanic rocks in the Piersko, Sokolniki, Kaźmierz and Rokietnica regions could be supplied by easterly and northeasterly winds, blowing from a hypothetical high located north-west of the Golęczewo 1 borehole, which is composed of volcanic rocks and aeolian sandstones, enriched in coarser grains (granules). In turn, sand and sand-gravel sheets found in the area of the Obrzycko 1 and Obrzycko 3 boreholes could be related to the same hypothetical high and to southeasterly winds. Such a high, composed of aeolian sandstones that occur between the Objezierze IG 1 and Golęczewo 1 boreholes, might have occurred in the relatively narrow Obrzycko-Szamotuły-Poznań tectonic zone. These sandstones were eroded prior to the Zechstein transgression, as it was the case of the area between Pniewy and Piersko (Fig. 24).

The prevalent northwesterly wind directions can be identified with a zone of the so-called "N.E. trade winds" circulation in the subtropical latitudes (Glennie, 1983a, b). The zone can 
move by as little as $10^{\circ}$ of latitude due to changes resulting from polar winter/summer seasons. The permanent shift of this zone could, for example, be caused by a "mini" glacial epoch on the Northern Hemisphere, and be related to regular major climatic cycles that are clearly marked in the development of Zechstein deposits (e.g., Peryt, 1984, 1986, 1989; Roscher and Schneider, 2006; Legler, 2006; Słowakiewicz et al., 2009; Legler and Schneider, 2013). An example of depositional mega-cyclicity that starts in the Rotliegend and continues in the Zechstein is given by Legler and Schneider (2013).

Minor climate fluctuations, that can cause significant changes in the directions of prevailing winds, should also be taken into account. This can result in the erosion of pre-existing aeolian forms and aggradation of new ones (Brookes, 2003).

\section{IMPLICATIONS}

The phenomenon of sand sheet formation is still unravelling, in terms of sedimentological analyses. An important question is whether the formation of an initial sand sheet causes its rapid aggradation, or whether the formation and development of sand sheets is associated with their steady development, which in fact controls the long-term stability of sedimentary conditions. Do sand sheets include a number of smaller genetic units, comprised of distinctive sets of laminae, separated by erosional bounding surfaces?

What time interval is "hidden" in thick sand sheet deposits, and do they contain significant sedimentary gaps (no sediment aggradation) caused by erosion, which in the core, are preserved in the form of flat erosive surfaces?

Can we consider the top of each such lamina set to represent a super surface or a sand drift surface?

A question also arises about the relationship between these super surfaces and the dune deposits of the erg. In aeolian dune deposits, multi-stage erosion (deflation) can cause destruction of earlier boundaries, hence the lateral correlation of the base and top boundaries of sand sheets may be difficult or impossible to determine.

Stabilization of sand sheets may result from specific stable hydrogeological conditions that develop in marginal zones of large ergs. This may involve the formation of a shallow, near-surface, flat and stable groundwater level. Stable groundwater level reflects stable palaeoclimatic conditions, characterized by a slightly humid period. Perhaps, the base of any significant sand sheet represents the beginning of climate wetting, and shows features of a sequence boundary.

\section{CONCLUSIONS}

The Rotliegend deposits of the Pniewy-Objezierze region represent three main sedimentary environments: aeolian desert (dunes and sand sheets), alluvial plains (alluvial covers with wadi deposits) and marginal playa. These environments interrelate, which is an example of interactions controlled mainly by palaeoclimate fluctuations. In dry periods, dunes prograded into areas dominated by alluvial sedimentation. In more wet periods, alluvial deposits eroded the aeolian deposits and prograded onto dune fields. The occurrence of playa deposits within aeolian or alluvial sediments was marked during periodic expansion of the playa.

The deposits are arranged in depositional sequences separated by, boundaries reflecting a rapid change in sedimentary environment, and by selected erosional surfaces. These deposits were accumulated in an arid and semi-arid climate with wetting periods. Maximum Wetting Surface have been distinguished within some parts of the depositional sequences, which enable regional correlations.

The Rotliegend sections are made up of thick sequences of sand and sand-gravel sheets. Their formation, extent, and thickness, in relation to other deposits, indicates specific conditions of long-term and invariable sedimentation. Thus, the sand sheets represent periods of stratigraphic condensation. Systems of sand sheets are typical of marginal areas of ergs.

In the upper depositional sequences, in the sections of sand sheets and some dune sandstones, coarsening-upward successions are found. Increasing grain size is also observed in the upper part of the Hannover Formation in the Rotliegend North German Basin. This trend may indicate a change in climatic conditions within the entire Southern Permian Basin. The trend is also interpreted as being related to a gradual regional increase in humidity.

The last, ninth depositional sequence (aeolian dunes) is fragmentarily preserved in the study area (Figs. 16 and 17). The remnants of former aeolian cover prove a wetting period and erosion of the Upper Rotliegend deposits, during a period preceding the Zechstein Sea transgression. The uppermost depositional sequence, Unit 9, could have originated from an extensive aeolian cover or a linear draa (analogous to the British Yellow Sands). The Yellow Sands developed during the last phase, preceding the Zechstein Sea transgression. Within the Obrzycko-Szamotuły-Goleczewo tectonic zone, the aeolian sandstones were probably uplifted and eroded during the period preceding the Zechstein Sea transgression. The fragmentarily preserved aeolian cover, of the ninth depositional sequence, may be an equivalent of the Hyde (Fm) and Akkrum (Mb) sandstones from the Dutch-British part of the Rotliegend Basin.

The authors conclude that the described depositional system of sand and sand-gravel sheets may be one of the most important in the entire Southern Permian Basin. As such, it represents a unique feature, or is evidence for a more common occurrence of sand sheets in the Rotliegend than has been previously thought.

Acknowledgements. The authors express their thanks to $\mathrm{K}$. Wolański and K. Chłódek for their kindness and valuable discussions on Rotliegend deposits. We also thank the staff of the Central Drill Core Storage Facility at Chmielnik, especially S. Chmielewski, as well as J. Wargin and Z. Kałaczyński from the former drill core storage facility in Piła for both help in making the cores available and particular interest in our project. Dr M. Dohnalik is appreciated for application of computed tomography method in petrophysical analysis of Rotliegend eolian sandstones in the Pniewy 4 core. Dr B. Legler is thanked for substantive comments to our geological ideas. We are grateful to Professor T. Peryt for his enthusiastic approach to our work and for belief that we were ever going to finish it. We owe our great thanks to the Geological Quarterly reviewers, S. Fryberger, R. Gast and A. Poszytek, for their numerous comments and inspiring remarks, and to Grace Fryberger for her proofreading and language editing of the manuscript. 


\section{REFERENCES}

Al-Masrahy, M.A., Mountney, N.P., 2015. A classification scheme for fluvial-aeolian system interaction in desert-margin settings. Aeolian Research, 17: 67-88.

Biswas, A., 2005. Coarse aeolianites: sand sheets and zibar-interzibar facies from the Mesoproterozoic Cuddapah Basin, India. Sedimentary Geology, 174: 149-160.

Biswas, A., Zimbelman, J., Hargitai, H., 2014. Zibar. In: Encyclopedia of Planetary Landforms. Springer.

Breed, C.S., McCauley, J.F., Davis, P.A., 1987. Sand sheets of the eastern Sahara and ripple blankets on Mars. Geological Society Special Publications, 35: 337-360.

Brookes, I.A., 2003. Geomorphic indicators of Holocene winds in Egypt's Western Desert. Geomorphology, 56: 155-166.

Brookfield, M.E., 1977. The origin of bounding surfaces in ancient aeolian sandstones. Sedimentology, 24: 303-332.

Buniak, A., 1999. Środowiska depozycji i rozwój sedymentacji górnego czerwonego spagowca w północnej części monokliny przedsudeckiej (rejon Poznań-Pniewy) (in Polish). Przegląd Geologiczny, 47: 465.

Buniak, A., Kiersnowski, H., 2010. Środowiska sedymentacji i paleogeografia zachodniej cześci ergu wschodniego basenu górnego czerwonego spagowca: wybrane przykłady (in Polish). In: IV Polska Konferencja Sedymentologiczna POKOS'4: Teraźniejszość kluczem do przeszłości: współczesne procesy sedymentacyjne i ich zapis kopalny. Smołdzino, 21-26 czerwiec 2010 r.

Chan, M.A., 1989. Erg margin of the Permian White Rim Sandstone, SE Utah. Sedimentology, 36: 235-251.

Chan, M.A., Hunter, R.E., Loope, D.P., Langford, R.P., 1992. Reflections on eolian and erg-margin systems. Conference Report. Journal of Sedimentary Petrology, 62: 917-920.

Chrintz, T., Clemmensen, L.B., 1993. Draa reconstruction, the Permian Yellow Sands, northeast England. IAS Special Publications, 16: 151-161.

Clemmensen, L.B., 1990. Preservation of interdraa and plinth deposits by the lateral migration of large linear draas (Lower Permian Yellow Sands, northeast England). Sedimentary Geology, 65: 139-151.

Clemmensen, L.B., Abrahamsen, K., 1983. Aeolian stratification and facies association in desert sediments, Arran basin (Permian), Scotland. Sedimentology, 30: 311-339.

Clemmensen, L.B., Tirsgaard, H., 1990. Sand-drift surfaces: a neglected type of bounding surface. Geology, 18: 1142-1145.

Dadlez, R., 1997. Tektonika kompleksu permsko-mezozoicznego. Ogólne rysy tektoniczne bruzdy śródpolskiej (in Polish). Prace Państwowego Instytutu Geologicznego, 153: 410-414.

Fryberger, S.G., Ahlbrndt, T.S., 1979. Mechanisms for the formation eolian sand seas. Zeitschrift für Geomorphologie, 23: 440-460.

Fryberger, S.G., Schenk, C.J., 1988. Pin stripe lamination: A distinctive feature of modern and ancient eolian sediments. Sedimentary Geology, 55: 1-15.

Fryberger, S.G., Ahlbrandt, T.S., Andrews, S., 1979. Origin, sedimentary features and significance of low-angle eolian "sand sheet" deposits, Great Sand Dunes National Monument and vicinity, Colorado. Journal of Sedimentary Petrology, 49: 733-746.

Fryberger, S.G., Hesp, P., Hastings, K., 1992. Aeolian granule ripple deposits, Namibia. Sedimentology, 39: 319-331.

Fryberger, S.G., Knight, R., Hern, C., Moscariello, A., Kabel, S., 2011. Rotliegend facies, sedimentary provinces, and stratigraphy, Southern Permian Basin UK and the Netherlands: a review with new observations. SEPM Special Publication, 98: 51-88.

Gast, R.E., 1991. The perennial Rotliegend saline lake in NW Germany. Geologisches Jahrbuch, A119: 25-59.

Gast, R.E., 1993. Sequenzanalyse von äolischen Abfolgen im Rotliegenden und deren Verzahnung mit Küstensedimenten. Geologisches Jahrbuch, A131: 117-139.

Gast, R.E., 1995. Sequenzstratigraphie. Courier Forschungsinstitut Senckenberg, 183: 47-54.

Gast, R., Dusar, M., Breitkreutz, Ch., Gaupp, R., Schneider, J.W., Stemmerik, L., Geluk, M., Geissler, M., Kiersnowski, H., Glen- nie, K., Kabel, S., Jones, N., 2010. Rotliegend. In: Petroleum Geological Atlas of the Southern Permian Basin Area (eds. H. Doornenbal and A. Stevenson): 101-122. TNO, The Netherlands.

Geißler, M., Breitkreuz, C., Kiersnowski, H., 2008. Late Paleozoic volcanism in the central part of the Southern Permian Basin (NE Germany, W Poland): facies distribution and volcano-topographic hiati. International Journal of Earth Sciences, 97: 973-989.

George, G.T., Berry, J.K., 1997. Permian (Upper Rotliegend) synsedimentary tectonics, basin development and palaeogeography of the Southern North Sea. Geological Society Special Publications, 123: 31-61

Glennie, K.W., 1983a. Early Permian (Rotliegendes) palaeowinds of the North Sea. Sedimentary Geology, 34: 245-265.

Glennie K.W., 1983b. Lower Permian Rotliegend desert sedimentation in the North Sea area. Developments in Sedimentology, 38: 521-541.

Głowacki, E., Rydzewska, K., Żurawek, E., Oziembłowski, P., 1993. Analiza litologiczno-sedymentacyjna i własności zbiornikowe utworów saksonu na obszarze Obrzycko-Pniewy-Poznań (in Polish). Arch. PGNiG S.A., Warszawa (OPR/G/1769).

Howell, J., Mountney, N., 1997. Climatic cyclicity and accomodation space in arid to semi-arid depositional systems: an example from the Rotliegend Group of the UK southern North Sea. Geological Society Special Publications, 123: 63-86.

Jackowicz, E., 1994. Permian volcanic rocks from the northern part of the Fore-Sudetic Monocline (in Polish with English summary). Prace Państwowego Instytutu Geologicznego, 145: 1-47.

Karnkowski, P., 1999. Oil and Gas Deposits in Poland. The Geosynoptics Society, University of Mining and Metallurgy, Cracow.

Karnkowski, P.H., 1994. Rotliegend lithostratigraphy in the central part of the Polish Permian Basin. Geological Quarterly, 38 (1): 27-42

Karnkowski, P.H., 1999. Orgin and evolution of the Polish Rotliegend Basin. Polish Geological Institute Special Papers, 3: 1-93.

Karpeta, W.P., 1990. The morphology of Permian paleodunes $-a$ reinterpretation of he Bridgnorth Sandstone around Bridgnorth, England, in the light of modern dune studies. Sedimentary Geology, 69: 59-75.

Kiersnowski, H., 1997. Depositional development of the Polish Upper Rotliegend Basin and evolution of its sediment source areas. Geological Quarterly, 41 (4): 433-456.

Kiersnowski, H., 2013. Late Permian aeolian sand seas from the Polish Upper Rotliegend basin in the context of palaeoclimatic periodicity. Geological Society Special Publications, 376: 431-456.

Kiersnowski, H., 2014. Early Permian sedimentary basins of Polish Variscan Externides. CPC-2014 Field Meeting on Carboniferous and Permian Nonmarine-Marine Correlation, Freiberg, Germany. Abstract Volume, p. 25.

Kiersnowski, H., 2015. Perm. Czerwony spagowiec. Charakterystyka sedymentologiczna utworów czerwonego spagowca (in Polish). Profile Głębokich Otworów Wiertniczych Państwowego Instytutu Geologicznego, 146: 47-59.

Kiersnowski, H., Buniak, A., 2006. Evolution of the Rotliegend Basin of northwestern Poland. Geological Quarterly, 50 (1): 119-138.

Kiersnowski, H., Tomaszczyk, M., 2010. Permian dune fields as geomorphic traps for gas accumulation: Upper Rotliegend Zechstein Basin, SW Poland. In: Abstracts Volume, 18th International Sedimentological Congress (eds. E. Schwarz, S. Georgieff, E. Piovano and D. Ariztegui): 944. Mendoza, Argentina.

Kiersnowski, H., Paul, J., Peryt, T.M., Smith, D.B., 1995. Facies, paleogeography and sedimentary history of the Southern Permian Basin in Europe. In: The Permian of Northern Pangea, 2 (eds. P.A. Scholle, T.M. Peryt and D.S. Ulmer-Scholle): 119-136. Springer, Berlin.

Kiersnowski, H., Peryt, T.M., Buniak, A., Mikołajewski, Z., 2010. From the intra-desert ridges to the marine carbonate island chain: middle to late Permian (Upper Rotliegend-Lower 
Zechstein) of the Wolsztyn-Pogorzela High, west Poland. Geological Journal, 45: 319-335.

Kocurek, G., 1988. First-order and super bounding surfaces in eolian sequences - bounding surfaces revisited. Sedimentary Geology, 56: 193-206.

Kocurek, G., Dott, R.H., 1981. Distinctions and uses of stratification types in the interpretation of eolian sand. Journal of Sedimentary Petrology, 51: 579-595.

Kocurek, G., Havholm, K.G., 1993. Eolian sequence stratigraphy a conceptual framework. AAPG Memoir, 58: 393-409.

Kocurek, G., Nielson, J., 1986. Conditions favorable for the formation of warm-climate aeolian sand sheets. Sedimentology, $\mathbf{3 3}$ 795-816.

Legler, B., 2006. Faziesentwicklung im Südlichen Permbecken in Abhängigkeit von Tektonik, eustatischen Meeresspiegelschwankungen des Proto-Atlantiks und Klimavariabilität. Schriften der Deutschen Gesellschaft für Geowissenschaften, 47: 3-103.

Legler, B., Schneider, J.W., 2008. Marine ingressions into the Middle/Late Permian saline lake of the Southern Permian Basin (Rotliegend, Northern Germany) possibly linked to sea-level highstands in the Arctic rift system. Palaeogeography, Palaeoclimatology, Palaeoecology, 267: 102-114.

Legler, B., Schneider, J.W., 2013. High-frequency cyclicity preserved in nonmarine and marine deposits (Permian, Germany and North Sea). New Mexico Museum of Natural History and Science Bulletin, 60: 200-211.

Leveille, G.P., Knipe, R., More, C., Ellis, D., Dudley, G., Jones, G., Fisher, Q.J., Allinson, G., 1997. Compartmentalization of Rotliegendes sandstone. Jupiter Field area, southern North Sea. Geological Society Special Publications, 123: 87-104.

Loope, D.B., 1985. Episodic deposition and preservation of eolian sands: a late Paleozoic example from southeastern Utah. Geology, 13: 73-76.

Maliszewska, A., Kiersnowski, H., Jackowicz, E., 2003. Lower Rotliegend volcaniclastic rocks at Wielkopolska (Western Poland) (in Polish with English summary). Prace Państwowego Instytutu Geologicznego, 179: 1-59.

McCann, T., Kiersnowski, H. (coord.), Krainer, K., Vozárová, A., Peryt, T.M., Oplustil, S., Stollhofen, H., Schneider, J., Wetzel, A., Boulvain, F., Dusar, M., Török, A., Haas, J., Tait, J., Körner, F., 2008. Permian. In: The Geology of Central Europe, 1 (Precambrian and Palaeozoic) (ed. T. McCann): 531-597. The Geological Society of London, London.

McKee, E.D., 1966. Structures of dunes at White Sand National Monument New Mexico and a comparison with structures of dunes from other selected areas. Sedimentology, 7: 3-69.

Maxwell, T.A., Haynes, C.V. Jr., 1989. Large-scale, low-amplitude bedforms (chevrons) in the Selima Sand Sheet, Egypt. Science, 243: 1179-1182.

Maxwell, T.A., Haynes, C.V., 2001. Sand sheet dynamics and Quaternary landscape evolution of the Selima Sand Sheet, southern Egypt. Quaternary Science Reviews, 20: 1623-1647.

Minervini, M., Rossi, M., Mellere, D., 2011. Cyclicity and facies relationships at the interaction between aeolian, fluvial, and playa depositional environments in the Upper Rotliegend: regional correlation across UK (Sole Pit basin), the Netherlands, and Germany. SEPM Special Publication, 98: 119-146.

Muszyński, M., 1999. Środowisko sedymentacji i spoiwo osadów górnego czerwonego spagowca obszaru niecki poznańskiej (in Polish). Przegląd Geologiczny, 47: 466-467.

Nielson J., Kocurek G., 1986. Climbing zibars of the Algodones. Sedimentary Geology, 48: 1-15.

Peryt, D., Peryt, T.M., Raczyński, P., Chłódek, K., 2012. Foraminiferal colonization related to the Zechstein (Lopingian) transgression in the western part of the Wolsztyn Palaeo-Ridge area, Western Poland. Geological Quarterly, 56 (3): 529-546.

Peryt, T.M., 1984. Sedimentation and early diagenesis of the Zechstein Limestone in Western Poland (in Polish with English summary). Prace Instytutu Geologicznego, 109: 1-70.

Peryt, T.M., 1986. Chronostratigraphical and lithostratigraphical correlations of the Zechstein Limestone of Central Europe. Geological Society Special Publications, 22: 201-207.
Peryt, T.M., 1989. Basal Zechstein in southwestern Poland: sedimentation, diagenesis, and gas accumulations. Geological Association of Canada, Special Paper, 36: 601-625.

Peryt, T.M., Ważny, H., 1980. Microfacies and geochemical development of the basin facies of the Zechstein Limestone (Ca1) in western Poland. Contributions to Sedimentology, 9: 279-306.

Peryt, T.M., Hałas, S., Peryt, D., 2015. Carbon and oxygen isotopic composition and foraminifera of condensed basal Zechstein (Upper Permian) strata in western Poland: environmental and stratigraphic implications. Geological Journal, 50: 446-464.

Pokorski, J., 1981. Formal lithostratigraphic subdivision proposed for the Rotliegendes of the Polish Lowlands (in Polish with English summary). Kwartalnik Geologiczny, 25 (1): 41-58.

Pokorski, J., 1988a. Palaeotectonic maps of the Rotliegendes in Poland (in Polish with English summary). Kwartalnik Geologiczny, 32 (1): 15-32.

Pokorski, J., 1988b. Rotliegendes lithostratigraphy in north-western Poland. Bulletin of the Polish Academy of Sciences, Earth Sciences, 36: 99-108.

Poszytek, A., 2014. Reservoir properties of the Upper Rotliegend and the Weissliegend sandstones (Permian) in the Zielona Góra Basin (western Poland). Geological Quarterly, 58 (1): 193-206.

Roescher, M., Schneider, J.W., 2006. Permo-Carboniferous climate: Early Pennsylvanian to Late Permian climate development of central Europe in regional and global context. Geological Society Special Publications, 265: 95-136.

Ryka, W., 1989. Rotliegendes volcanics, sediment lithologies and paleoenvironments, and Polish Basin history: an overview. Geological Association of Canada, Special Paper, 36: 627-633.

Schröder, L., Plein, E., Bachmann, G.H., Gast, R.E., Gebhardt, U., Graf, R., Helmuth, H.-J., Pasternak, M., Proth, H., Süssmuth, S., 1995. Stratigraphische Neugliederung des Rotliegend im Norddeutschen Becken. Geologisches Jahrbuch, A148: 3-21.

Sharp, R.P., 1963. Wind ripples. Journal of Geology, 71: 617-636.

Simplicio, F., Basilici, G., 2015. Unusual thick eolian sand sheet sedimentary succession: Paleoproterozoic Bandeirinha Formation, Minas Gerais. Brazilian Journal of Geology, 45 (Suppl. 1): 3-11.

Słowakiewicz, M., Kiersnowski, H., Wagner, R., 2009. Correlation of the Middle and Upper Permian marine and terrestial sedimentary sequences in Polish, German, and USA Western Interior Basins with reference to global time markers. Palaeoworld, 18: 193-211.

Steele, R.P., 1983. Longitudinal draa in the Permian Yellow Sands of north-east England. Developments in Sedimentology, 38: $543-550$.

Sweet, M.L., 1999. Interaction between aeolian, fluvial and playa environments in the Permian Upper Rotliegend Group, UK southern North sea. Sedimentology, 46: 171-187.

Sweet, M.L., Nielson, J., Havholm, K., Farralley, J., 1988. Algodones dune field of southeastern California: case history of a migrating modern dune field. Sedimentology, 35: 939-952.

Van Ojik, K., Bohm, A.R., Cremer, H., Geluk, M.C., De Jong, M.G.G., Mijnlieff, H.F., Nio, S.D., 2011. The Permian Rotliegend of the Netherlands. SEPM Special Publication, 98: 37-48.

Wagner, R., 1994. Stratigraphy and evolution of the Zechstein Basin in the Polish Lowland (in Polish with English summary). Prace Państwowego Instytutu Geologicznego, 153.

Wierzchowska-Kicułowa, K., 1984. Geology of the pre-Permian series of the Fore-Sudetic Monocline (in Polish with English summary). Geologia Sudetica, 19: 121-142.

Weihe, T., 1997. Sedimentologie und Fazies des Rotliegenden (unteres Perm) nördlich des Wolsztyn-Hochs, Westpolen, im Spiegel der Beckenentwicklung. Clausthaler Geowissenschaftliche Dissertationen, $\mathbf{5 1}$

Yang, C., Nio, S.D., 1993. Applications of high-resolution sequence stratigraphy to the Upper Rotliegend in the Netherlands offshore. AAPG Memoir, 58: 285-316. 